\title{
A Satellite-Based Assessment of the Distribution and Biomass of Submerged Aquatic Vegetation in the Optically Shallow Basin of Lake Biwa
}

\author{
Shweta Yadav ${ }^{1}$ (D), Minoru Yoneda ${ }^{1}$, Masayuki Tamura ${ }^{2}$, Junichi Susaki ${ }^{2}$, Kanako Ishikawa ${ }^{3}$ \\ and Yosuke Yamashiki ${ }^{4, *}$ \\ 1 Department of Environmental Engineering, Graduate School of Engineering, Kyoto University, \\ Kyoto 615-8540, Japan; shweta@risk.env.kyoto-u.ac.jp (S.Y.); yoneda@risk.env.kyoto-u.ac.jp (M.Y.) \\ 2 Department of Civil and Earth Resources Engineering, Graduate School of Engineering, Kyoto University, \\ Kyoto 615-8540, Japan; tamuram@envinfo.uee.kyoto-u.ac.jp (M.T.); susaki.junichi.3r@kyoto-u.ac.jp (J.S.) \\ 3 Lake Biwa Environmental Research Institute (LBERI), Otsu 520-0022, Japan; ishikawa-k@lberi.jp \\ 4 Graduate School of Advanced Integrated Studies in Human Survivability, Kyoto University, \\ Kyoto 606-8501, Japan \\ * Correspondence: yamashiki.yosuke.3u@kyoto-u.ac.jp; Tel.: +81-75-762-2080
}

Received: 15 July 2017; Accepted: 12 September 2017; Published: 18 September 2017

\begin{abstract}
Assessing the abundance of submerged aquatic vegetation (SAV), particularly in shallow lakes, is essential for effective lake management activities. In the present study we applied satellite remote sensing (a Landsat- 8 image) in order to evaluate the SAV coverage area and its biomass for the peak growth period, which is mainly in September or October (2013 to 2016), in the eutrophic and shallow south basin of Lake Biwa. We developed and validated a satellite-based water transparency retrieval algorithm based on the linear regression approach $\left(R^{2}=0.77\right)$ to determine the water clarity (2013-2016), which was later used for SAV classification and biomass estimation. For SAV classification, we used Spectral Mixture Analysis (SMA), a Spectral Angle Mapper (SAM), and a binary decision tree, giving an overall classification accuracy of $86.5 \%$ and SAV classification accuracy of $76.5 \%$ (SAV kappa coefficient 0.74 ), based on in situ measurements. For biomass estimation, a new Spectral Decomposition Algorithm was developed. The satellite-derived biomass $\left(R^{2}=0.79\right)$ for the SAV classified area gives an overall root-mean-square error (RMSE) of $0.26 \mathrm{~kg}$ dry weight (DW) $\mathrm{m}^{-2}$. The mapped SAV coverage area was $20 \%$ and $40 \%$ in 2013 and 2016, respectively. Estimated SAV biomass for the mapped area shows an increase in recent years, with values of $3390 \mathrm{t}$ (tons, dry weight) in 2013 as compared to $4550 \mathrm{t}$ in 2016. The maximum biomass density (4.89 $\mathrm{kg} \mathrm{DW} \mathrm{m}^{-2}$ ) was obtained for a year with high water transparency (September 2014). With the change in water clarity, a slow change in SAV growth was noted from 2013 to 2016. The study shows that water clarity is important for the SAV detection and biomass estimation using satellite remote sensing in shallow eutrophic lakes. The present study also demonstrates the successful application of the developed satellite-based approach for SAV biomass estimation in the shallow eutrophic lake, which can be tested in other lakes.
\end{abstract}

Keywords: submerged aquatic vegetation (SAV); water transparency; SAV biomass; remote sensing; shallow lake

\section{Introduction}

Historically, there has been considerable interest in submerged aquatic vegetation (SAV), as it is intricately involved in the aquatic food web and significantly influences the freshwater ecosystem [1-4]. On the other hand, the rampant overgrowth of invasive SAV species in natural lakes and streams 
has also received much attention recently from water engineers and research scientists [5-9]. When present, large SAV beds sequester nutrients, provide habitats for fish and other invertebrates, prevent sediment re-suspension, and thus maintain clear water conditions in shallow water bodies $[4,10,11]$. Dense macrophyte cover competes for the nutrients and releases the allelochemicals that are suspected to inhibit the growth of phytoplankton and avert eutrophication [12,13]. Re-establishment of SAV has also been recognized as an important ecological technique for the restoration of the eutrophic lakes $[14,15]$. Conversely, the massive overgrowth of invasive SAV species is associated primarily with the anthropogenic nutrient enrichment in freshwater ecosystems, and it is likely to have an impact, environmentally or economically. In particular, invasive aquatic plants alter the nutrient cycles, degrade water quality, dominate native species, and obstruct navigation, fishery and other recreational activities $[5,6,16]$. In Japan, over 40 alien aquatic plant species have already been naturalized and have proliferated in many lakes and river beds [17]. The most dominant alien species commonly found in Japanese lakes are Egeria Densa and Elodea Nuttallii. Egeria Densa (also known as Brazilian waterweed) which is a submerged aquatic plant with relatively fast growth rate, thrives in low light conditions to a water depth of $4 \mathrm{~m}$, and can invade freshwater systems with its dense canopy formation [18].

Previous works have demonstrated the feasibility of mapping and monitoring the SAV cover in the large lakes using satellite remote sensing [8,19-21]. Aerial photographs and high resolution airborne hyperspectral images have been used for vegetation mapping to overcome spatial heterogeneity in the optically complex aquatic environment $[16,22,23]$. However, due to the large area coverage, ease of data acquisition, and low costs associated with the medium resolution satellite image (e.g., Landsat Thematic Mapper (TM)/Enhanced Thematic Mapper (ETM)/Operational Land Imager (OLI), Spot, Terra/Aster) they are widely used for mapping SAV along with other limnologic parameters $[8,24,25]$. Satellite remote sensing is a potential tool for monitoring the growth and characteristics of SAV in fresh waters $[19,26-30]$. The principles behind aquatic vegetation and terrestrial vegetation spectral characteristics are same, however, aquatic plants are not easily detectable due to the complex aquatic environment as compared to the environment of their terrestrial counterparts [27].

In optically shallow water, the detection of SAV using remote sensing is often hindered by the absorption and scattering processes of the optically active components (OAC), mainly phytoplankton (chlorophyll a), non-phytoplankton suspended sediments (NPSS) and cDOM (chromophoric dissolved organic matter) $[27,31-34]$. The presence of OAC potentially diminishes the water transparency which limits plant growth and reduces the possibility of detecting submerged plants using satellite images $[35,36]$. In order to map the SAV species in lake water, their reflectance must cross the air-water interface, which is not possible in the highly turbid water. Nevertheless, if the water is less turbid and the SAV signal significantly contributes to the water leaving reflectance, then it is possible to map the distribution of SAV using satellite images [23,35]. Hence, water clarity is an important factor substantially influencing the detection of SAV by satellite remote sensing [20]. In a eutrophic lake, the mixed pixel effect due to the presence of OAC can result in misclassification. Thus, it is essential to have water clarity information before SAV classification. Consequently, in some studies, the satellite images were used to estimate the water transparency [37] and optical depth (water clarity or transparency) assessment [26], before SAV abundance mapping. Most frequently used approach for water clarity estimation involves the linear regression of the satellite bands and the in situ water clarity data [37-40].

In addition, several remote sensing techniques have been used for SAV spectral analysis and bottom mappings. Some of the frequently used techniques include vegetation presence frequency [22], vegetation indices [38,41], the radiative transfer model and linear mixture approach [31,41], the modular inversion program, and the Water Color Simulator (WASI) $[23,42]$ and classification tree model $[43,44]$. Moreover, high spatial resolution imagery such as the Quickbird multispectral image was applied in some studies for SAV mapping [45]. Techniques using the Spectral Angle Mapper (SAM) [46], Spectral Mixture Analysis (SMA) [16], and Continuum Removal and Minimum Noise 
Fraction (MNF) [29] were successfully applied mainly to hyperspectral images for aquatic vegetation mapping and identification $[16,23,28,29,47]$. However, the application of these techniques to medium resolution satellite images such as those obtained with Landsat- 8 is still insufficient, especially for classifying and mapping the SAV in the shallow eutrophic lakes.

Furthermore, to quantitatively assess the growth of SAV communities, biomass estimation is essential. SAV biomass is an important factor indicating the productivity of the lake ecosystem. Conversely, excessive plant material (i.e., the biomass) also contributes to the plant nuisance problem in shallow waters [48-50]. Remote sensing techniques such as the Submerged Aquatic Vegetation Mapping Algorithm (SAVMA) were used to estimate the SAV biomass (mainly Cladophora) by assigning the average dry weight density obtained from the field survey to the identified SAV area (i.e., grouped as the dense and less dense Cladophora area) [26]. In contrast, in some studies an aquatic vegetation biomass estimation model was developed by establishing a relationship between the Normalized Difference Vegetation Index (NDVI) and the observed biomass of aquatic plants, using multispectral satellite images [39]. In the former case, a different set of dry weight estimates is required to estimate the biomass for other time of the year. In the latter case, the NDVI values of SAV can be influenced by the presence of phytoplankton, particularly in eutrophic lakes [40]. The time-specific and location-specific approach may not be applicable in other optically shallow lakes.

In this study, we developed a new biomass estimation approach based on the Spectral Decomposition Algorithm. The algorithm conceptualizes the mixed pixel reflectance and expresses it as a linear combination of the potential endmembers (i.e., OAC). The Spectral Decomposition Algorithm has previously been used only for water quality monitoring for the shallow lakes using three main OAC, i.e., clear water, NPSS and phytoplankton [51,52]. Nevertheless, in optically shallow waters, the upward irradiance just below the water surface is the sum of the flux backscattered by the water column and the flux reflected by the bottom [31,53-56]. Thus, when analyzing the remote sensing data for optically shallow lakes, the influence of the bottom albedo has to be included $[23,53]$. Specifically, this applies for lakes with long stands of dense vegetation substrate which substantially contribute to the water, leaving reflectance. However, the influence of the bottom substrate has not been accounted for using the same algorithm in the previous studies, which could be due to the different environmental conditions of their study areas.

To address the gaps in monitoring the SAV in the shallow eutrophic lakes, the present study aims to develop a satellite-based approach for SAV distribution and biomass mapping using the Landsat-8 Operational Land Imager (OLI) image for the SAV peak growth period, mainly in September (2013-2016). The main purpose of the study was further divided into three objectives: (1) to estimate the water transparency of the shallow eutrophic lake; (2) to identify and map the SAV distribution area in the shallow lake; and (3) to develop a satellite-based SAV biomass estimation approach for the SAV area detected using the satellite image. The water transparency determination was primarily used to confirm the turbid water area for SAV mapping and for SAV biomass model development.

This study presents the new Spectral Decomposition Algorithm to quantify the SAV biomass for the classified SAV pixels in the optically complex, eutrophic, and shallow lake, using the medium resolution satellite image. The developed approach accounts for the bottom albedo thus, with accurate water clarity information, this can be utilized as an important tool to assess the SAV abundance in the shallow water bodies. Furthermore, the satellite-based (i.e., Landsat-8) approach developed in this study also provides a cost-effective method for the frequent monitoring of SAV, which could apply to large lakes.

\section{Materials and Methods}

\subsection{Study Area}

Lake Biwa $\left(35^{\circ} 20^{\prime} 59.48^{\prime \prime} \mathrm{N}\right.$ and $\left.136^{\circ} 10^{\prime} 33.16^{\prime \prime} \mathrm{E}\right)$ is located in the central Honshu Island, southwest of Japan (Figure 1). The lake surface area is $670 \mathrm{~km}^{2}$ and it has a total catchment area of $3838 \mathrm{~km}^{2}$. 
The lake encompasses two basins, the north basin $\left(618 \mathrm{~km}^{2}\right)$ which is mesotrophic and deep (the mean and the maximum depths are $44 \mathrm{~m}$ and $104 \mathrm{~m}$, respectively), and the south basin $\left(52 \mathrm{~km}^{2}\right)$ which is eutrophic and shallow (the mean and the maximum depths are $3.5 \mathrm{~m}$ and $8 \mathrm{~m}$, respectively). In this paper, depth is also called water depth. The water level in the Lake Biwa is controlled by the Seta River Weir located in the south basin. The standard water level in the lake is $85 \mathrm{~m}$ above sea level (a.s.l). Water level does not change significantly in the lake. For SAV growth period the maximum and minimum water levels observed were $+0.3 \mathrm{~m}$ to $-0.5 \mathrm{~m}$ (from the standard water level), respectively [21,57]. Several small rivers drain into the Lake Biwa, which means the Seta River is the only natural outlet in the south basin. The lake serves as an important water source for agriculture, industries, and fishery while also providing drinking water for over 14 million people in the Kansai region. It has also been designated as a registered wetland under the Ramsar Convention since 1993.

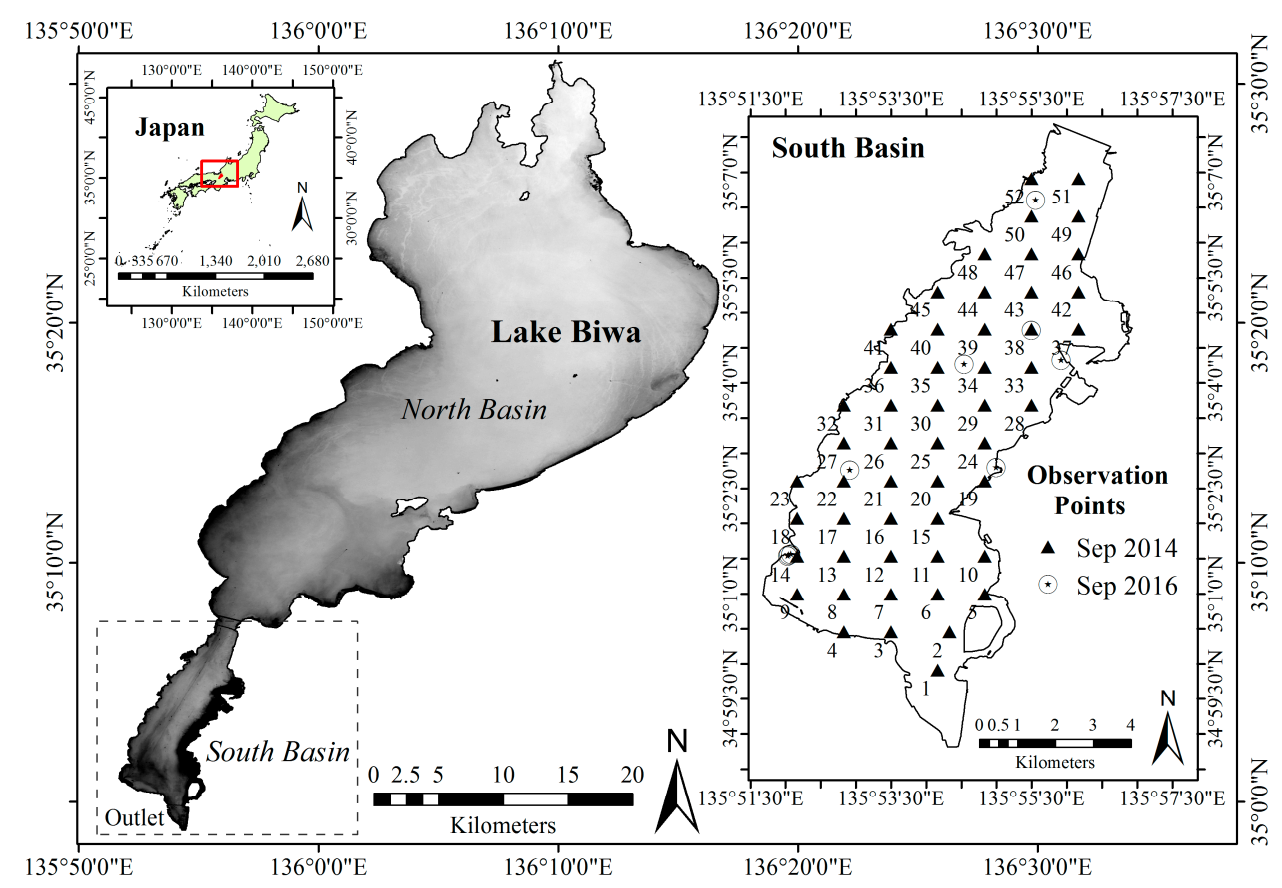

Figure 1. Geographical location of Lake Biwa and its southern basin with water quality and submerged aquatic vegetation (SAV) observation points.

Lake Biwa (mainly the south basin of Lake Biwa) experienced eutrophication during the economic growth period after the 1960s. The lake is located in the Kinki region of Japan, which receives an annual precipitation of $1279 \mathrm{~mm}$ (monthly average range $45-184 \mathrm{~mm}$ ) and has a mean temperature of $16{ }^{\circ} \mathrm{C}$, although the maximum temperature can reach $35^{\circ} \mathrm{C}$ (Japan Meteorological Agency (JMA) (http:/ / www.jma.go.jp/jma/indexe.html)) [58]. Climate change is considered an important driver resulting in eutrophication and affecting the lake ecosystem [57]. In the south basin of Lake Biwa, the observed minimum and maximum water surface temperatures were $27^{\circ} \mathrm{C}$ and $34^{\circ} \mathrm{C}$ (September 2016), respectively. The land use change in the catchment area is attributed mainly to the ongoing urbanization and change in industrial structure in the periphery of the south basin, contributing to eutrophication. Also, the south basin is surrounded by farmland, mainly paddy fields. To curb the eutrophication and to restore the lake ecosystem, the Shiga Prefectural Government enacted the ordinance Prevention of Eutrophication of Lake Biwa in 1979 followed by the formulation of the Water Quality Conservation Plan in 1986. Consequently, water quality of the lake improved which led to an upsurge in the growth of submerged macrophytes in the lake [57]. The Lake underwent an ecological regime shift from the phytoplankton-dominated turbid water lake to macrophyte-dominated clear water lake in 1994. The regime shift was believed to be triggered by a severe water shortage when the 
water level reached to its lowest at $-1.23 \mathrm{~m}$ (the standard water level of $0 \mathrm{~m}$ corresponds to $85 \mathrm{~m}$ a.s.l, in Lake Biwa), in the same year. This reduced water level allowed sufficient light penetration in the water column for aquatic vegetation to grow. Consequently, submerged macrophytes recovered in the lake with increased transparency and improved water quality [57]. The coverage of submerged macrophytes in the southern basin increased dramatically from $6 \mathrm{~km}^{2}$ in 1994 to $50 \mathrm{~km}^{2}$ in 2014, covering more than $90 \%$ of the lake bottom [22,59]. The prolific growth of invasive alien species such as Egeria Densa and Elodea Nuttallii has reduced the dispersal and biomass of the native SAV species, Vallisneria Asiatica var. Biwaensis in the past few decades [57]. The dense community of submerged macrophytes lowered the oxygen saturation to less than $50 \%$, just above the lake bottom and adversely impacted navigation and fisheries in recent years [60,61]. Large masses of submerged macrophytes detach from the bottom and drift up to the lake shore every year, which affects the landscape value of the lake. To avert the nuisance overgrowth of SAV, local authorities and the Shiga Prefectural Government invested a sizable effort and expense in harvesting the submerged macrophytes as an active macrophyte control effort. In general, the changes in SAV percent cover, stand height, and biomass are monitored using the traditional site-specific diver survey collecting the sample from a grid size of $50 \mathrm{~cm} \times 50 \mathrm{~cm}$, which cannot accurately account for the spatial variation in the basin. In Lake Biwa, the basin-wise assessment of the spatial extent of SAV cover and biomass is limited, primarily because the in situ survey of large lakes using traditional methods is time-consuming and cost-prohibitive [22,57,59,62].

Recently, the total submerged macrophyte biomass in the southern basin doubled from 9623 tons dry weight (2007) (hereafter t DW) to 18,173 t DW (2014), approximately. According to Haga and Ishikawa (2016) [59], the dominant SAV species in the basin are Potamogeton Maackianus, Elodea Nuttallii, Hydrilla Verticillata and Egeria Densa. As of September 2014 (the peak growth period of SAV), the average concentration of phytoplankton, suspended sediment (SS) and dissolved organic carbon (DOC) measured in the south basin is $10.9 \mu \mathrm{g} / \mathrm{L}, 1.1 \mathrm{mg} / \mathrm{L}$, and $1.5 \mathrm{mg} / \mathrm{L}$, respectively. The images of SAV growth were taken during the field survey as shown in Figure 2.

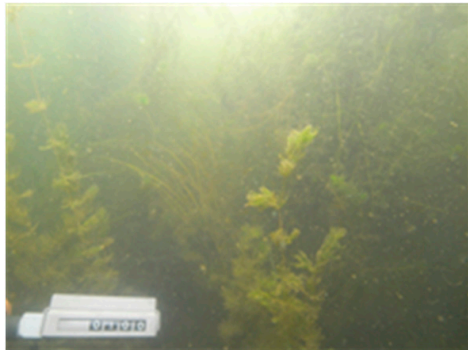

(a) September 2013

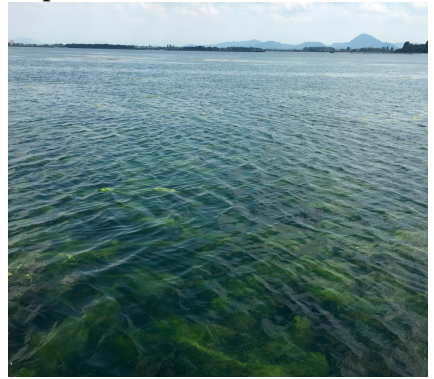

(d) September 2016

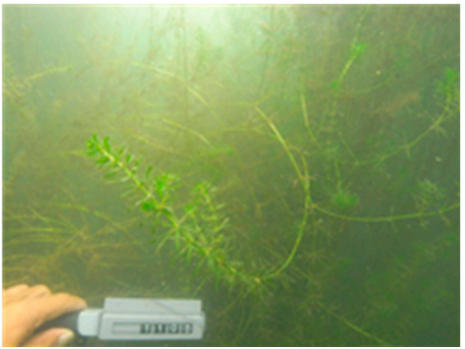

(b) October 2013

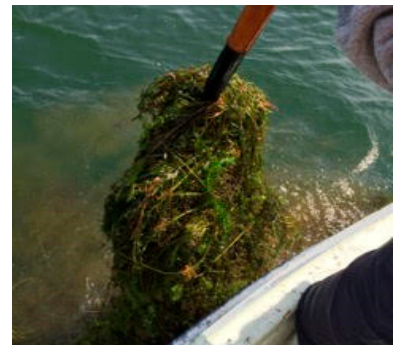

(c) September 2015

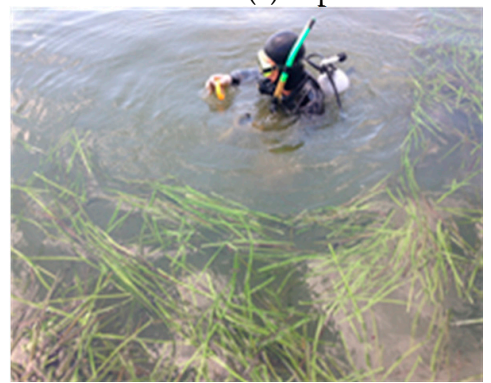

(e) September 2016

Figure 2. In-field images of the SAV in the south basin. The September and October 2013 images of the SAV at the lake bottom were provided by the Japan Water Agency (a,b). September 2015 and 2016 images were taken during field survey by LBERI (c) and September 2016 images were taken during the In situ measurement (d,e). LBERI: Lake Biwa Environmental Research Institute. 


\subsection{Data Sources}

\subsubsection{Field Data}

Owing to the limited in situ measurements and data matching with the Landsat- 8 image acquisition time spatially and temporally, we used the water transparency data available for September-October 2013 in this study. The water transparency data (200 points) were obtained from the Japan Water Agency (JWA) (http:/ / www.water.go.jp) [63] from September to October 2013. However, only 95 transect points were in the range of \pm 5 days of satellite image acquisition time (1 October 2013). For September 2014, the Lake Biwa Environmental Research Institute (LBERI) in Otsu provided the in situ measured data of 52 observation points, which include chlorophyll a $(\mu \mathrm{g} / \mathrm{L})$, SAV biomass in grams dry weight per square meter (hereafter $\mathrm{g} \mathrm{DW} \mathrm{m}^{-2}$ ), and water depth $(\mathrm{m})$. On 2 September (2016), with LBERI we surveyed (using a small boat) a total of eight observation points located in the south basin. We measured the SAV biomass and its stand height (i.e., the total plant height from the lake bottom to the top of the plant canopy). Furthermore, we also measured chlorophyll a, total suspended solids (TSS in $\mathrm{mg} / \mathrm{L}), \mathrm{DOC}(\mathrm{mg} / \mathrm{L})$, water depth (i.e., total depth from the water surface to the lake bottom), and spectral reflectance.

We first measured the spectral reflectance at each observation point using the ASD FieldSpec ${ }^{\mathrm{TM}}$ Pro JR Field Portable Spectroradiometer with a sampling interval of $1.4 \mathrm{~nm}$ between 350 and $1000 \mathrm{~nm}$, and of $2 \mathrm{~nm}$ between 1000 and $2500 \mathrm{~nm}$, using the software RS3. The measurements were made from a nadir position where the sensor head (i.e., $5^{\circ}$ field of view) was mounted on a fixed iron rod (extending to $1.5 \mathrm{~m}$ away from the boat, beyond its shading effect) located $1 \mathrm{~m}$ above the water surface. Also, we kept the sun-sensor azimuth at $90^{\circ}$ and the viewing zenith angle at $45^{\circ}$ which corresponds to the minimum of sun-glint [31], simultaneously avoiding the shadows and reflections from the sampling platform. At all the locations, the reflectance measurements were taken while keeping the boat stationary and visually confirming the minimum disturbances in the water by the boat. The inappropriate measurements due to any disturbances (e.g., disturbances by the boat, viewing geometry) were removed from the data set. At each site, 5-7 measurements were taken between at 10:00 and 15:00 local time under clear weather conditions. The observation points were selected based on the distribution of homogeneous patches of SAV species and their abundance (referring to September 2014 SAV biomass data and LBERI expert suggestions). During sampling, we found that SAV sample from each location contains the mixture of more than one species. At the same time, we also found the dominance of at least one species. Therefore, we measured the reflectance of each species measured individually in the dark experiment room with a 500-W halogen light using the spectroradiometer. The reflectance spectra of each species were measured 5-6 times and averaged to eliminate any potential variation in the illumination. In this study, the reflectance calculated between $400 \mathrm{~nm}$ to $900 \mathrm{~nm}$ was used because of the low signal-to-noise ratio at the longer wavelengths.

Afterward, for the same locations we collected water samples in a polyethylene bottle (at a depth of $0.3 \mathrm{~m}$ from the water surface at each location) and they were stored in a dark and cold box containing ice during sampling. Samples were filtered immediately in the laboratory within $18 \mathrm{~h}$ of sampling using $0.47 \mu \mathrm{m}$ of Whatman GF/F ( $0.7 \mu \mathrm{m}$ pore size) glass fiber filters. Chlorophyll a was extracted using $90 \%$ ethanol. The extraction tubes were left overnight in the refrigerator (temperature $4{ }^{\circ} \mathrm{C}$ ) before measuring concentrations using the spectrophotometer (Photolab ${ }^{\circledR} 6100$ VIS Series) [64]. Subsequently, TSS concentration was determined gravimetrically by drying the Whatman GF/F filters at $103-104^{\circ} \mathrm{C}$ for three hours. We also measured DOC concentration using the Total Organic Carbon (TOC) Analyzer (TOC-5000A, Shimadzu Kyoto, Japan). Furthermore, we calculated non-phytoplankton suspended sediment (NPSS) by subtracting concentration of phytoplankton suspended sediment (PSS) from TSS [51].

Subsequently, at each location, a $50 \mathrm{~cm} \times 50 \mathrm{~cm}$ of quadrat was used (by diver survey) to measure the SAV coverage and species biomass. The SAV samples were harvested along with their roots (i.e., pulled out completely) from the $0.25 \mathrm{~m}^{2}$ of the quadrat area by the scientific diver (professional diver 
working for LBERI). Because the survey was conducted with LBERI, we followed their method of SAV sample collection in order to maintain the consistency of the data using the same method used for the past years by LBERI to monitor the SAV biomass [22,62]. The position of each quadrat was recorded using a global positioning system (GPS) followed by the camera photographs of the sampled site. The fresh weight ( $\mathrm{g}$ wet weight $\mathrm{m}^{-2}$ ) of the SAV species from each quadrat were measured in the LBERI lab immediately after sampling. Afterward, the samples were dried at $60^{\circ} \mathrm{C}$ for $48 \mathrm{~h}$ in a drying oven to determine the dry weight $\left(\mathrm{g} \mathrm{DW} \mathrm{m}^{-2}\right)$ [48].

In this study, we conducted in situ measurements in conjunction with LBERI. Therefore, not much variation is expected between the surveyed data for 2014 and the data collected from LBERI for the other years $(2013,2015$ and 2016).

\subsubsection{Remotely Sensed Data}

The Landsat-8 OLI images were acquired for the peak growth period of SAV in Lake Biwa, mainly in September (1 October 2013, 9 September 2014, 28 September 2015, and 7 September 2016). The details of the data collected during this study are given in Table 1.

Because the cloud-free image for September 2013 was not available, we used an image from 1 October 2013. We downloaded images based on survey time, geographical extent and environmental conditions (cloud-free and wind speed $<3 \mathrm{~m} / \mathrm{s}$ ), obtained from U.S. Geological Survey (USGS) EarthExplorer (https:/ / earthexplorer.usgs.gov/) [65].

Image rectification and geoprocessing were achieved using ENVI 5.2 image analysis software and ArcMap 10.3.1. Apart from rescaling to top of atmosphere (TOA) reflectance, the images were atmospherically corrected using the mid-latitude summer atmospheric model and maritime aerosol model in the atmospheric correction module FLAASH of ENVI 5.2. Horizontal visibility of the study area was obtained from the closest stations (Kyoto and Hikone) from the Japan Meteorological Agency (JMA) and also from the weather and climate data information website (http:/ / www.weatherandclimate.info/) [66]. It varied from 16 to $25 \mathrm{~km}$ for September (2013-2016). The water area from the images was masked (i.e., extracted from the image for classification) for aquatic vegetation classification and mapping. Due to the changes in the sensor and atmospheric conditions over time, the satellite images of a different time may result in different pixel values. Therefore, to apply the developed technique to other satellite data, the image normalization was performed for 2013, 2015, and 2016 images (using the September 2014 atmospherically-corrected image as the reference image). The images were normalized using the relative radiometric normalization technique following Elvidge et al. (1995) and Oyama et al. (2009) [51,67]. The validation of the atmospherically-corrected Landsat-8 image with the in situ data (September 2016) is shown in Figure 3. Because of the time lag between image acquisition and In situ measurements, a perfect match between the satellite-derived and In situ measured reflectance (i.e., by FieldSpec Spectroradiometer) could not be achieved in this study. 
Table 1. Available data information for the south basin of Lake Biwa (2013-2016).

\begin{tabular}{|c|c|c|c|c|c|c|c|c|}
\hline \multirow{2}{*}{ Data Collected } & \multirow{2}{*}{ Data Sources } & \multicolumn{4}{|c|}{ Available Data/Locations/Time } & \multirow{2}{*}{$\begin{array}{c}\text { Training } \\
\text { Locations/Points }\end{array}$} & \multirow{2}{*}{$\begin{array}{c}\text { Validation } \\
\text { Locations/Points }\end{array}$} & \multirow{2}{*}{ Methods/Algorithms } \\
\hline & & 2013 (Sep-Oct) & 2014 (Sep) & 2015 (Sep) & 2016 (Sep) & & & \\
\hline Water depth $(\mathrm{m})$ & LBERI & - & 52 & - & 8 & - & - & - \\
\hline Water transparency $(\mathrm{m})$ & JWA & 95 & - & - & - & 42 & 53 & $\begin{array}{l}\text { Water Transparency } \\
\text { Retrieval Algorithm }\end{array}$ \\
\hline Water quality (Chlorophyll-a, TSS, DOC) & LBERI & - & 52 & - & 8 & - & - & - \\
\hline SAV biomass and stand height (diver survey) & $\begin{array}{l}\text { In situ survey, } \\
\text { LBERI }\end{array}$ & - & $\begin{array}{c}52 \text { (1 location for } \\
\text { emerged vegetation } \\
\text { was excluded) }\end{array}$ & - & 8 & 23 & $\begin{array}{l}17 \text { (2014) and } \\
8 \text { (2016) }\end{array}$ & $\begin{array}{c}\text { Spectral Decomposition } \\
\text { Algorithm-Biomass } \\
\text { Estimation Model }\end{array}$ \\
\hline (Training and validation points): & \multirow{8}{*}{$\begin{array}{l}\text { LBERI, Japan Water } \\
\text { Agency (JWA), In } \\
\text { situ survey }\end{array}$} & & & & & $(2013,14,15,16)$ & $(2013,14,15,16)$ & \multirow{8}{*}{$\begin{array}{l}\text { Binary decision tree } \\
\text { (NDVI, NIR, SWIR, } \\
\text { SMA, SAM) }\end{array}$} \\
\hline SAV & & 30 & 27 & 27 & 25 & $13,10,10,8$ & $17,17,17,17$ & \\
\hline Turbid Water & & 10 & 22 & 12 & 12 & $4,7,5,5$ & $6,15,7,7$ & \\
\hline Clear Water & & 6 & 18 & 7 & 8 & $3,6,3,3$ & $3,12,4,5$ & \\
\hline Emergent-V & & 6 & 2 & 6 & 3 & $3,1,3,1$ & $3,1,3,2$ & \\
\hline Floating-V & & 5 & 3 & 3 & 4 & $2,1,1,2$ & $3,2,2,2$ & \\
\hline Soil & & 8 & 8 & 8 & 8 & $4,3,3,3$ & $4,5,5,5$ & \\
\hline (from Imagery, Photographs and Field data) & & & & & & & & \\
\hline Spectral reflectance (spectroradiometer) & In situ survey & - & - & - & 8 & - & - & - \\
\hline Satellite images (Landsat-8 OLI) & USGS-Earth-Explorer & 1 Oct & 9 Sep & 28 Sep & 7 Sep & - & - & - \\
\hline Horizontal visibility $(\mathrm{km})$ & $\begin{array}{l}\text { JMA, weather and } \\
\text { climate data }\end{array}$ & 2 & 2 & 2 & 2 & - & - & - \\
\hline
\end{tabular}

Sep and Oct: means in September and October. TSS: total suspended solids; JWA: Japan Water Agency; DOC: dissolved organic carbon; NDVI: Normalized Difference Vegetation Index; NIR: near-infrared; SWIR: shortwave-infrared; SMA: Spectral Mixture Analysis; SAM: Spectral Angle Mapper; OLI: Operational Land Imager; USGS: U.S. Geological Survey. 


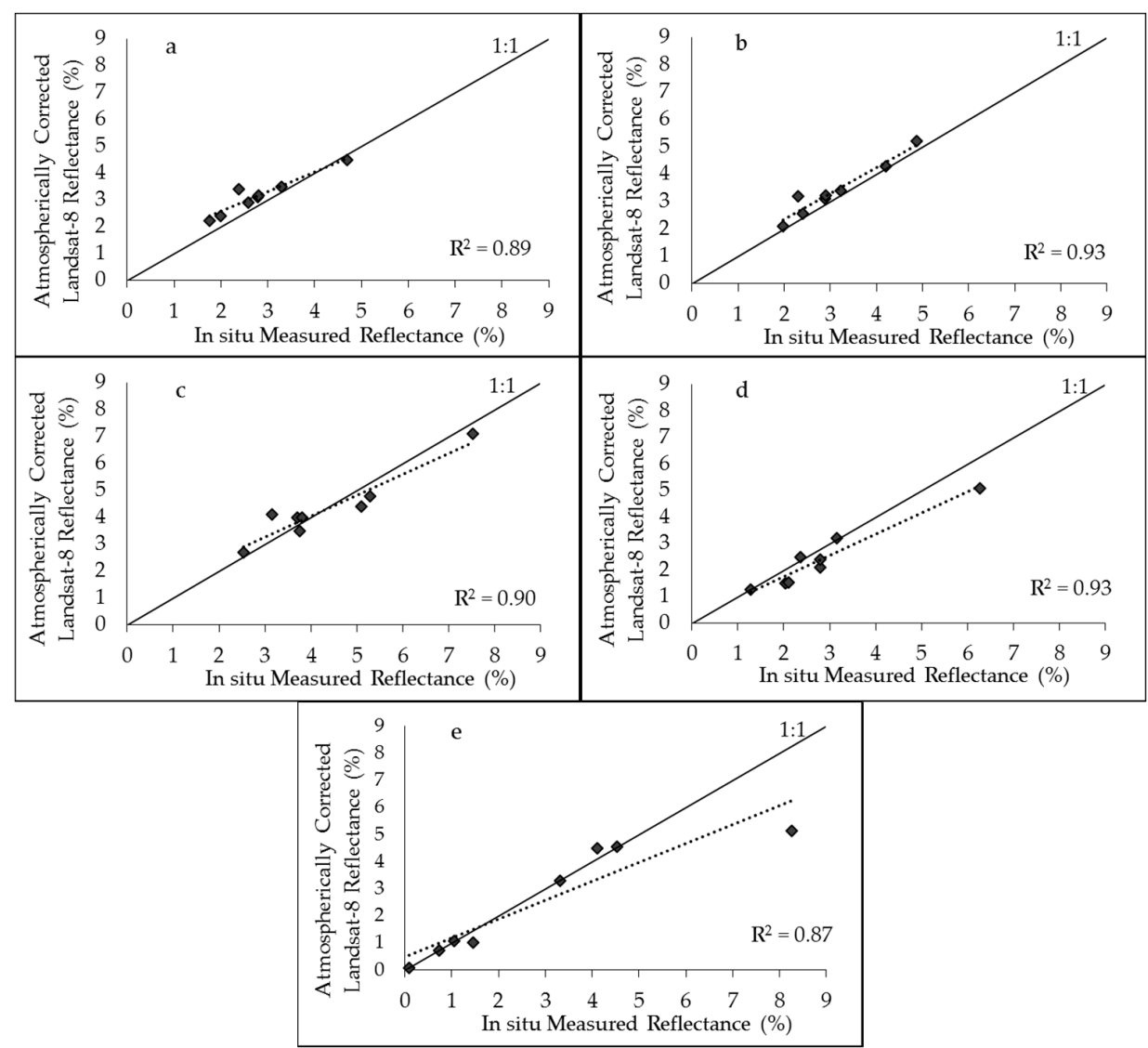

Figure 3. Comparison of atmospherically corrected Landsat- 8 band reflectance (September 2016 image) and in situ measured reflectance (i.e., by FieldSpec Spectroradiometer) of eight locations surveyed in September 2016. Given bands are: (a) band 1, (b) band 2, (c) band 3, (d) band 4, and (e) band 5.

\subsection{Methods}

The methods used in this study are shown in the flowchart (Figure 4).

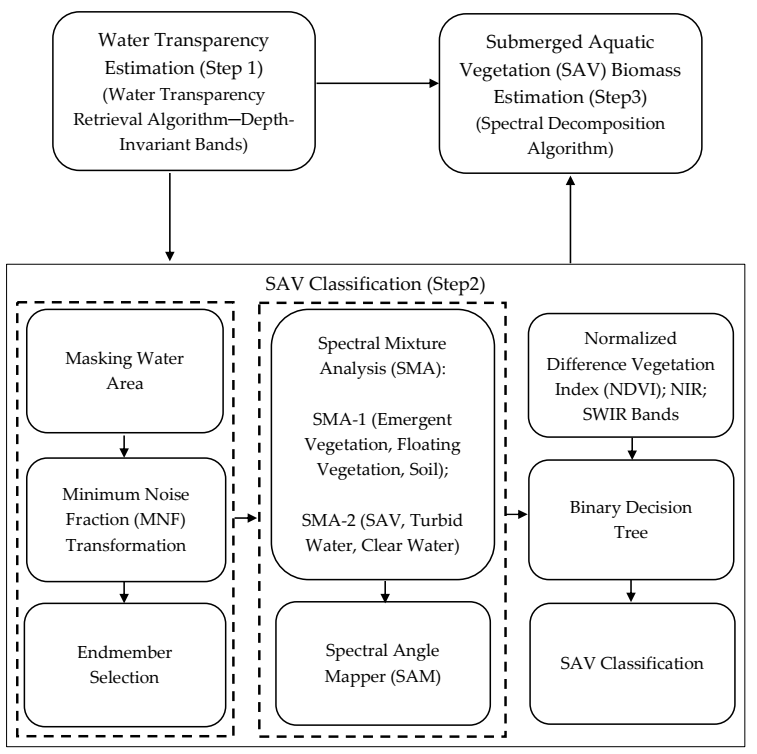

Figure 4. Methodology flowchart indicating the contribution of each step (steps 1 and 2) in SAV biomass estimation (step 3). 


\subsubsection{Water Transparency Retrieval Algorithm}

The relation between shallow and deep water radiance can provide the optical depth information in a lake [56]. In contrast, the combination of two or more bands can contribute to bottom albedo correction as well as determining the water depth $[25,68]$. Therefore, to estimate the water clarity, using a similar approach a linear relation between the observed water transparency (October 2013) and the depth-invariant reflectance of Landsat-8 bands was established, which is given by Equations (1) and (2).

$$
\begin{gathered}
Z_{W T}=a+b_{i}\left(X_{i}\right)+b_{j}\left(X_{j}\right), \\
X=\ln \left[R_{C}(\lambda)-R_{\infty}(\lambda)\right],
\end{gathered}
$$

In this study, the two-band combination gave the best result. The indices $i$ and $j$ represent the green and red bands; $a$ and $b$ are the constants determined by multiple linear regression whereas, $R_{C}$ and $R_{\infty}$ imply the Landsat- 8 corrected water leaving reflectance and optically deep water reflectance, respectively. To obtain the deep water reflectance, we identified the pixel (minimum pixel value) located in relatively clear and deep water area, based on the bathymetry map and the survey information. Subsequently, the minimum pixel values using the near-infrared (NIR) and shortwave-infrared (SWIR) reflectance bands were also confirmed for the same area $[25,56,69]$. The developed regression model that gave a good fit $\left(R^{2}=0.72\right.$, significance at $p<0.001$, standard error $\left.=0.38 \mathrm{~m}\right)$ with the observed water transparency data is given in Equation (3):

$$
Z_{W T}=-2.890+0.183 \times \ln \left[\left(R_{\text {green }}-R_{\infty}\right)\right]-1.299 \times \ln \left[R_{\text {Red }}-R_{\infty}\right],
$$

Out of 95 observed water transparency points, we used 53 for the result validation. The validated model was then used to retrieve the water clarity information for the images from 2014, 2015, and 2016.

\subsubsection{SAV Classification Approach}

The SAV signals are largely attenuated by water and the OAC concentration with increases in water depth. Additionally, the mixed pixel effect specifically in the eutrophic shallow lake makes it difficult to identify the SAV in the complex and dynamic aquatic environment. Thus, to map the $\mathrm{SAV}$, it is essential to isolate its signal from the confounding influences in the lake water. We therefore used linear Spectral Mixture Analysis (SMA) with ENVI 5.2, which can divide each pixel into the representative fraction of selected endmembers, where each endmember consists of the spectra of the key components on the ground [47]. However, to find the best combination of endmembers for the mixed pixel reflectance, a matrix inversion was performed using Equation (4).

$$
\begin{gathered}
R_{C i}=\sum_{j=1}^{n} f_{j} R E_{i j}+\varepsilon_{i}, \\
0 \leq \sum_{j=1}^{n} f_{j} \leq 1,
\end{gathered}
$$

where, $R_{C i}$ is a corrected pixel reflectance of band $i$; $f_{j}$ the fraction of endmember $j$ in the image; $R E_{i j}$ is the endmember $j$ reflectance at band $i ; n$ the number of endmembers; $\epsilon_{i}$ is the residual error of band $i$. The number of possible endmembers will always be less than the number of bands.

The Minimum Noise Fraction (MNF) transformation was applied to the Landsat-8 images before SMA to select the appropriate bands and exclude the bands with negligible information [30]. Importantly, before applying these techniques, we explicitly removed the undesired pixels such as terrestrial pixels by water mask. However, to eliminate other sources of confusion (e.g., bright land pixels nearshore of the south basin and boats) which may not have been removed by the water mask, we performed SMA using the prominent endmembers (land, aquatic vegetation, and water). The endmember spectra were identified individually for each year by manually selecting the pixels using the field data and 2-D scatter plot generated from the MNF transformed images. For instance, 
for 2014 MNF-transformed band 3 (green band) and band 4 (red band) with low noise were used to develop the 2-D scatter plot as shown in Figure 5. The reflectance spectra obtained for each endmember by manually selected pixels (based on the ground reference data) are displayed in Figure 6.

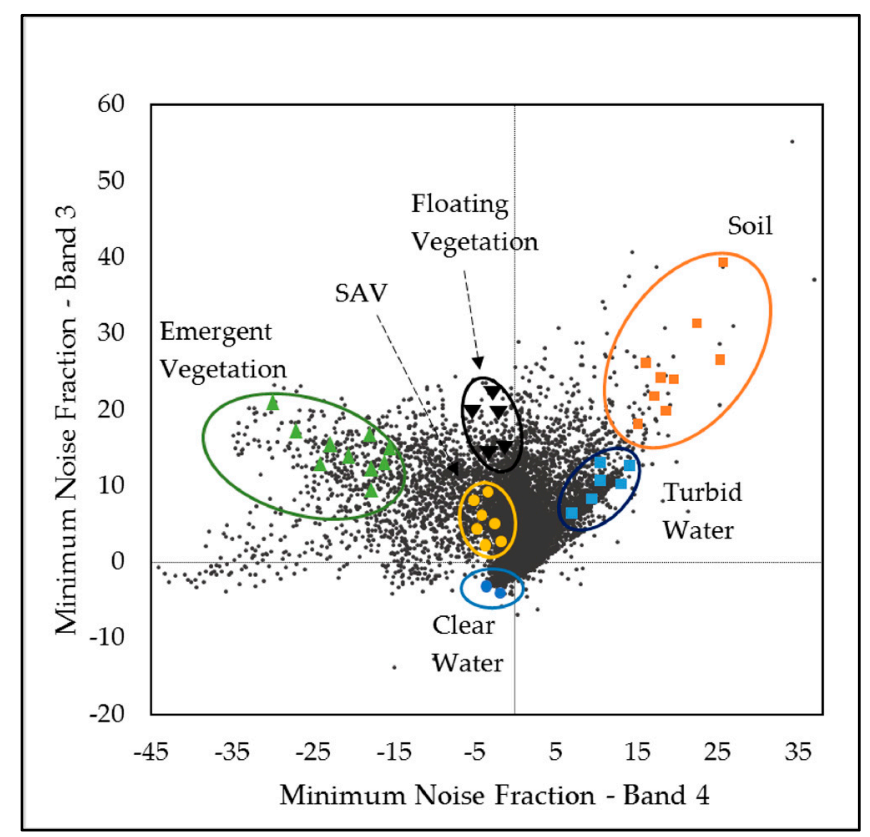

Figure 5. An endmember 2-D scatter plot derived from Minimum Noise Fraction (MNF)-transformed Landsat- 8 images (Band 3 and Band 4). The manually selected pixels extracted from the image use the ground reference data for September 2014.

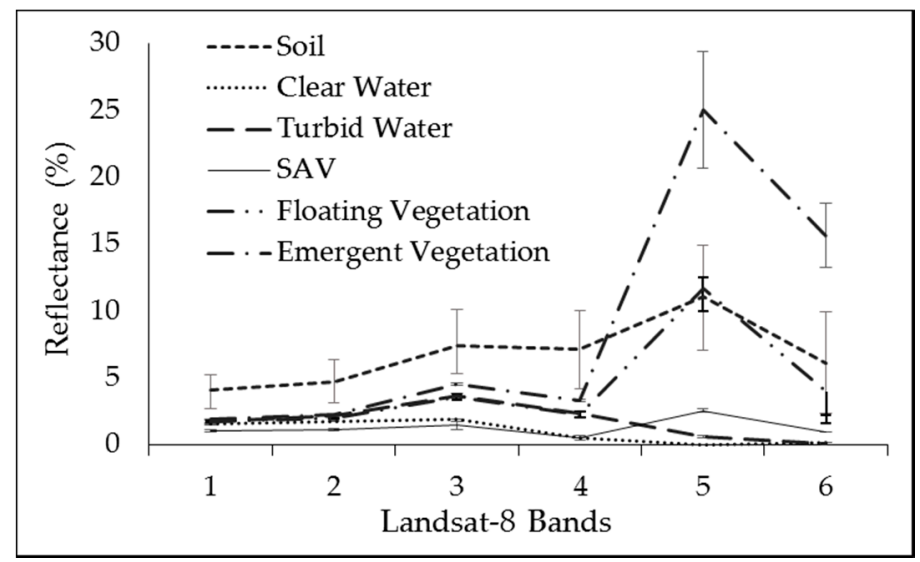

Figure 6. Endmember spectra extracted from Landsat-8 imagery (i.e., mean of the manually selected pixels) using the ground reference data from September 2014.

\subsubsection{Binary Decision Tree}

A decision tree approach (Figure 7) was used to classify and isolate the SAV pixels, where each node of the tree reduces the variance in the remaining pixels to be classified. The 2014 field data (52 observation points and the points selected based on the area information and photographs) were separated into training and validation data for the decision tree as given in Table 1. The SMA was used in conjunction with the Normalized Difference Vegetation Index (NDVI) to discriminate the emergent and floating vegetation from lake water. The SMA fraction used for SAV and turbid water as shown in Figure 7 does not vary much. Therefore, we used the same SMA fraction for each image 
(2013-2016). The emergent and floating vegetation have a distinctively higher albedo than SAV, turbid water, and clear water in the Landsat- 8 SWIR and NIR bands, as well as in the NDVI image. Thus, the reflectance of these bands was used in the decision tree to distinguish SAV from other emergent vegetation and turbid water. The NDVI and the reflectance of Landsat- 8 SWIR and NIR bands for each class were used to decide the classification thresholds for the binary decision tree. Similarly, the classification thresholds for all four images (2013-2016) were determined individually and are given in Table 2. The similar approach was used to classify SAV for each year (2013-2016) and then confirmed with the in situ measurement (ground reference data points) and the area information (i.e., area photographs).

Table 2. Classification thresholds based on the vegetation index and reflectance of NIR and SWIR bands of Landsat-8 atmospherically-corrected images (2013-2016).

\begin{tabular}{ccccccccccccc}
\hline & \multicolumn{3}{c}{$\mathbf{2 0 1 3}$} & \multicolumn{3}{c}{$\mathbf{2 0 1 4}$} & \multicolumn{3}{c}{$\mathbf{2 0 1 5}$} & \multicolumn{2}{c}{$\mathbf{2 0 1 6}$} \\
\cline { 2 - 12 } & NIR & SWIR & NDVI & NIR & SWIR & NDVI & NIR & SWIR & NDVI & NIR & SWIR & NDVI \\
\hline Land $(>)$ & 0.13 & 0.07 & & 0.11 & 0.06 & & 0.08 & 0.06 & & 0.13 & 0.10 & \\
Emergent $(>)$ & 0.20 & 0.12 & 0.69 & 0.25 & 0.13 & 0.72 & 0.18 & 0.10 & 0.70 & 0.28 & 0.15 & 0.75 \\
Floating $(>)$ & 0.07 & 0.03 & 0.36 & 0.09 & 0.04 & 0.49 & 0.05 & 0.04 & 0.43 & 0.09 & 0.04 & 0.43 \\
SAV $(\leq)$ & 0.02 & 0.01 & & 0.04 & 0.03 & & 0.04 & 0.02 & & 0.05 & 0.03 & \\
Turbid Water $(>)$ & 0.004 & 0.002 & & 0.007 & 0.002 & & 0.008 & 0.002 & & 0.01 & 0.004 \\
Clear Water $(<)$ & 0.001 & 0.001 & & 0.001 & 0.001 & & 0.001 & 0.001 & & 0.002 & 0.001 \\
\hline
\end{tabular}

For each year (i.e., 2013-2016), based on the available data (Table 1) and the satellite-derived water transparency data, the fixed ground control point was selected to derive the endmember spectra along with the 2-D scatter plot to confirm the distinct spectra of each endmember. Likewise, we generated the SAV distribution maps for 2013 and 2015. The in-field images of SAV (Figure 2) were also used to confirm the results. For the 2013 and 2015 images, the areas where the emergent, floating, and SAV vegetation can commonly be found in the basin were first identified using the true color image and the NDVI images. Additionally, the classified SAV maps of 2014 and 2016 were used to locate the common areas where the occurrence of SAV, emergent, and floating vegetation is most likely. Finally, using the same approach we were able to map the extent of SAV distribution for the peak growth period of 2013. In each image, the training and validation classes were selected based on the area information for that particular year. However, we found that out of all training and validation points, some are commonly found in all the four images. The training and validation locations for each class which are common in all four images (2013-2014) are shown in Figure 8. However, for each image, the training and validation points are not limited to the common locations as shown in Figure 8. Furthermore, from the selected locations in each image, we manually selected the pixels representing the classes. Because the aerial photographs for the south basin of the Lake Biwa was not available for the period (2013-2016) of the image acquisition, we used a Landsat-8 natural color image (October 2013) to demarcate the locations from each class. We further confirmed the selected locations based on the camera photographs taken during the in situ measurement and also the photographs provided by the JWA and LBERI. Furthermore, in the absence of aerial photographs, we used a Google Earth Pro 7.3.0 image to confirm the classes which do not change much within a month or remain unchanged throughout the season. For instance, the location marked for emergent vegetation does not show significant variation throughout the SAV growth period, for all the years (2013-2016). In addition, the turbid water location shown in the image receives the agricultural runoff from the surrounding area, thus remaining turbid and rich in nutrients with slight variation throughout the year $[57,62]$. 


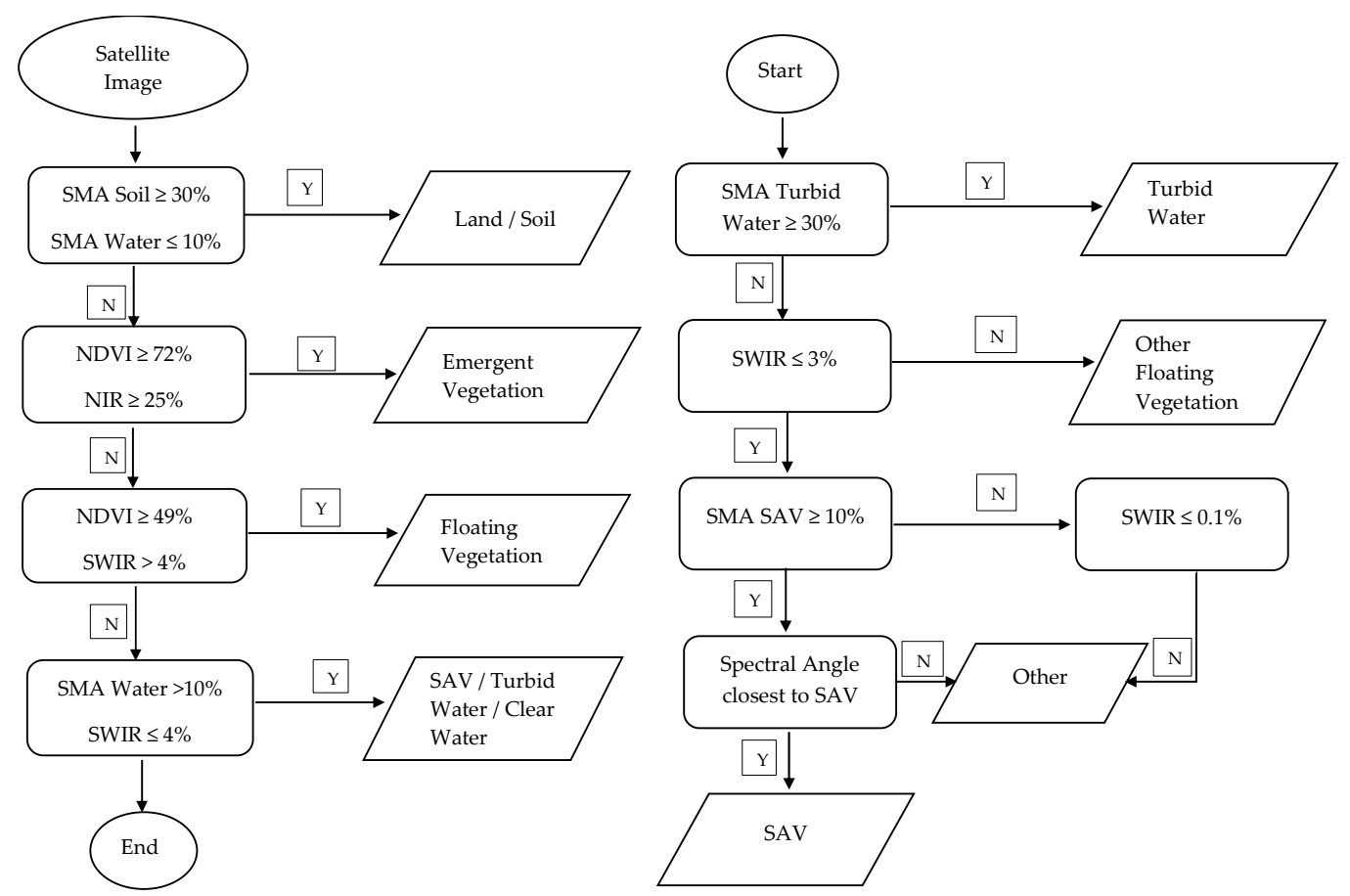

Figure 7. Decision tree classification developed for the extraction of land, emergent, and floating vegetation (left), and the extraction of SAV pixels from the turbid and clear water from the lake water (right). The two decision trees are in continuity from left to right (note: $\mathrm{Y}=$ Yes; $\mathrm{N}=\mathrm{No}$ ).

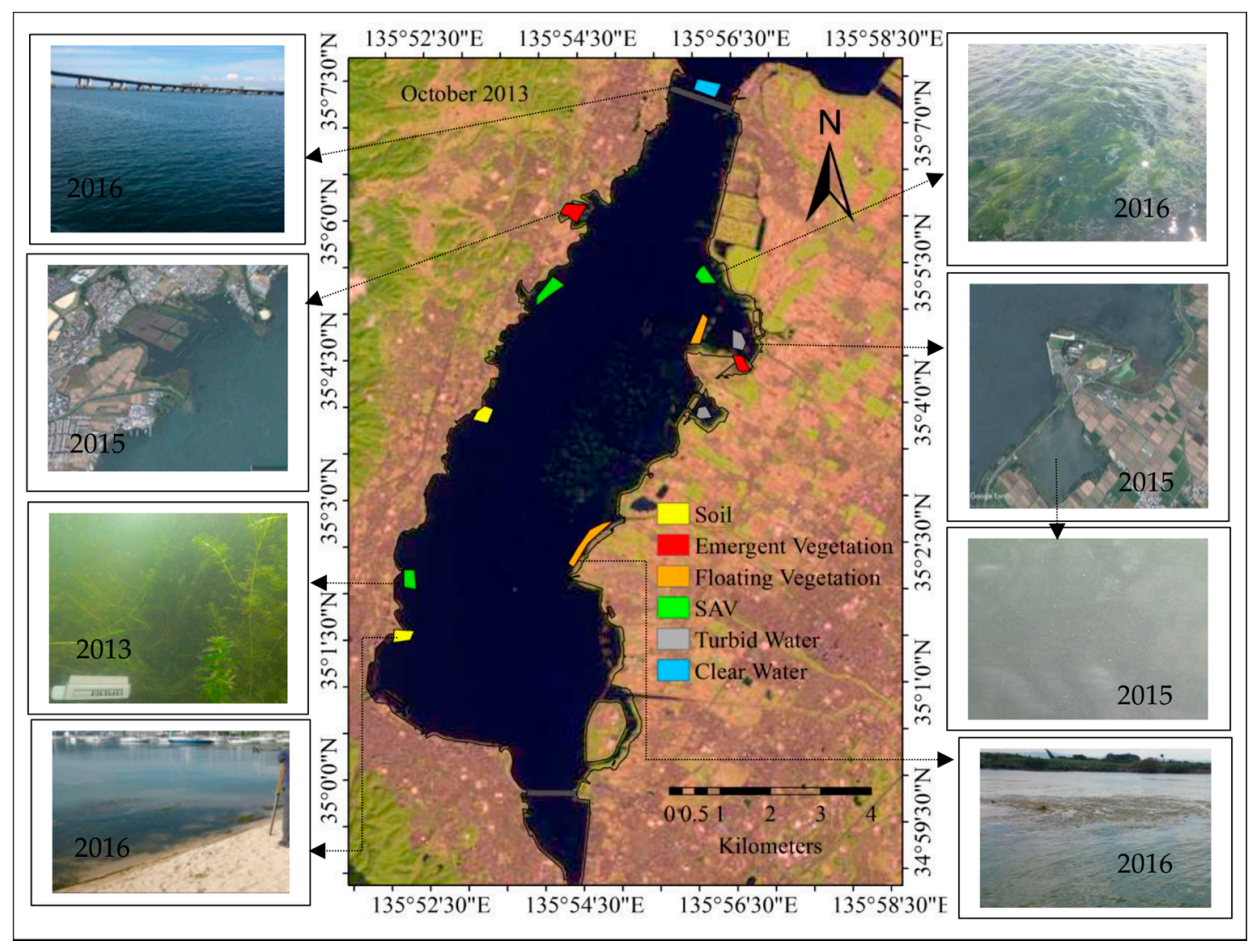

Figure 8. The selected common locations in the study area represent the specific class (for training and validation) for classification (2013-2016). From each location, pixels were manually selected. The images were obtained from the Japan Water Agency (JWA), Lake Biwa Environmental Research Institute (LBERI), the in situ measurements (September 2016) and Google Earth Pro version 7.3.0. The natural color image used in the map is from October 2013, and Google Earth image is from August 2015. 


\subsubsection{SAV Biomass Estimation}

For the biomass estimation of the classified SAV pixels, we developed a new model based on the spectral decomposition algorithm [51]. In this algorithm, the mixed reflectance spectra of a given pixels are conceptualized as a linear combination of potential endmembers substantially contributing to the pixel reflectance. Previously, this approach has been used to estimate the water quality parameters using the endmembers mainly from the water column of the lake [52,54]. However, in the shallow south basin of Lake Biwa, over $90 \%$ of the bottom is covered with SAV [21,59], which can potentially affect the pixel reflectance, and is likely to be confused with other algae or phytoplankton reflectance. Therefore, we included SAV as an important endmember for this study. The mixed pixel reflectance in the Spectral Decomposition Algorithm is expressed as in Equation (5).

$$
R(\lambda)=a_{p} \times R_{p}(\lambda)+a_{n} \times R_{n}(\lambda)+a_{v} \times R_{v}(\lambda)+a_{w} \times R_{w}(\lambda),
$$

where $a_{p}, a_{n}, a_{v}$ and $a_{w}$ symbolize the decomposition coefficients of phytoplankton, NPSS, SAV, and water, respectively. $R_{p}, R_{n}, R_{v}$ and $R_{w}$ represent the standard reflectance spectra of phytoplankton, NPSS, SAV, and water, respectively. Four decomposition coefficients were estimated by applying Equation (5) to each of the Landsat- 8 bands (i.e., band 1 to band 5) individually, which gave a total of five equations (e.g., for band 1, Equation (5.1)). In this study, the combination of blue, green, red and NIR bands gave the best results, evaluated by the $R^{2}$ value (significance at $p<0.01$ ). Thus, four out of five equations were used to estimate the decomposition coefficients.

$$
R\left(\lambda_{1}\right)=a_{p} \times R_{p}\left(\lambda_{1}\right)+a_{n} \times R_{n}\left(\lambda_{1}\right)+a_{v} \times R_{v}\left(\lambda_{1}\right)+a_{w} \times R_{w}\left(\lambda_{1}\right),
$$

The wavelength is expressed by $\lambda$ while $1,2,3,4$, and 5 represent coastal, blue, green, red, and NIR bands of the Landsat- 8 image.

To apply the Spectral Decomposition Algorithm to satellite images, initially, we tried to derive the standard reflectance spectra of each endmember from the image itself. However, due to the mixed pixel reflectance, particularly in shallow turbid water, identifying the spectrally pure pixel for phytoplankton and NPSS reflectance was not possible. This is because turbid water area with high phytoplankton concentration often has a high suspended solid concentration (as is the case in the south basin of Lake Biwa). Therefore, standard reflectance spectra of the endmembers were simulated using the Bio-Optical model, shown in Equation (6). The details of the equation can be found in Lee et al. (1998) [53] and Oyama et al. (2009) [51].

$$
\begin{aligned}
r_{r s}=(0.070+ & \left.0.16 u^{0.752}\right) u\left(1-1.03 \times \operatorname{Exp}\left\{-\left[\frac{1}{\cos \left(\theta_{W}\right)}+1.2(1+2.0 u)^{0.5}\right]\left(a+b_{b}\right) H\right\}\right) \\
& +0.31 \rho \times \operatorname{Exp}\left\{-\left[\frac{1}{\cos \left(\theta_{W}\right)}+1.1(1+4.9 u)^{0.5}\right]\left(a+b_{b}\right) H\right\},
\end{aligned}
$$

where $r_{r s}$ is the subsurface reflectance, $a$ and $b_{b}$ are the total absorption and backscattering coefficient, respectively, contributed by the pure water, phytoplankton, NPSS, and CDOM in the water column. In addition, $\theta_{w}$ indicates the subsurface solar zenith angle, $H$ indicates the bottom depth $(\mathrm{m})$, and $\rho$ indicates the remote sensing reflectance of the shallow water. Whereas, $u$ can be expressed by $a$ and $b_{b}$ as in Equation (7).

$$
u \equiv \frac{b_{b}}{a+b_{b}},
$$

Before the simulation, the Bio-Optical model was calibrated with the in situ measured reflectance (September 2016) using the average reflectance of the stations representing the environmental conditions of the satellite acquisition day. The ratio of the mean simulated and observed reflectance was calculated and multiplied with the simulated standard spectra of the satellite for each endmember, which was reintegrated into Landsat-8 bands (Figure 9). The standard reflectance spectra for each 
endmember was simulated in the following conditions, (a) phytoplankton (chlorophyll-a (chl-a) = $120 \mu \mathrm{g} / \mathrm{L}$, NPSS $=0 \mathrm{mg} / \mathrm{L}$ ); and (b) NPSS (chl-a $=0 \mu \mathrm{g} / \mathrm{L}$, NPSS $=100 \mathrm{mg} / \mathrm{L}$ ). Due to the low concentration of DOC observed in the south basin $(<3 \mathrm{mg} / \mathrm{L})$, we did not examine its influence in this study.

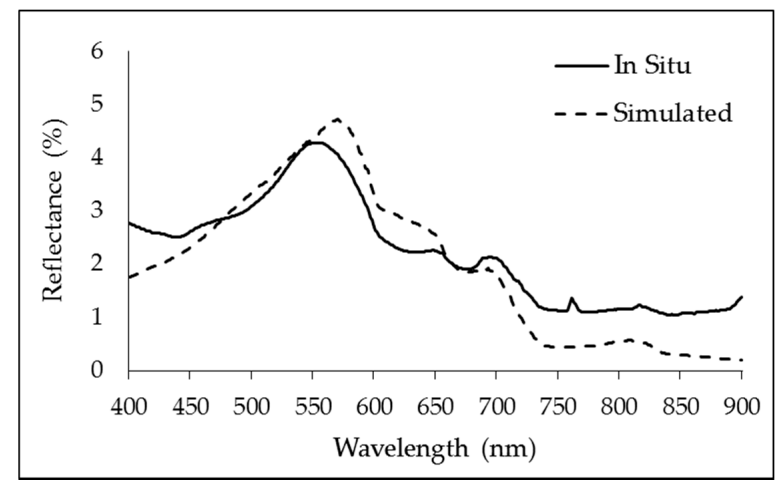

Figure 9. The mean simulated and observed reflectance using three stations in September 2016.

The SAV reflectance (measured without water using the spectroradiometer in the laboratory) was then simulated at different water depths ( $0.1 \mathrm{~m}$ to $2 \mathrm{~m}$ ) using the Bio-Optical model, before selecting the standard reflectance spectra. However, the SAV spectra simulated at a minimum water depth $(0.1 \mathrm{~m})$ was chosen as the standard reflectance spectra for SAV, as the water attenuation at $0.1 \mathrm{~m}$ is significantly lower than other $(>0.1 \mathrm{~m})$ water depths (Figures 10 and 11$)$.

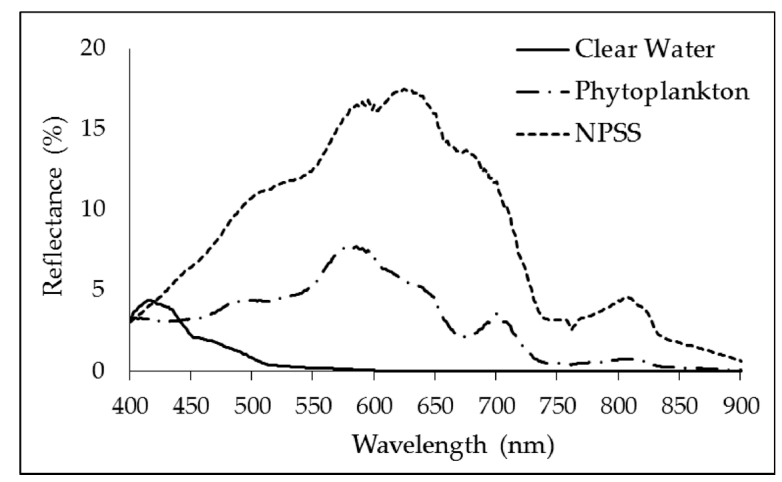

Figure 10. The standard reflectance spectra of three endmembers simulated using the Bio-Optical model. NPSS: non-phytoplankton suspended sediments.

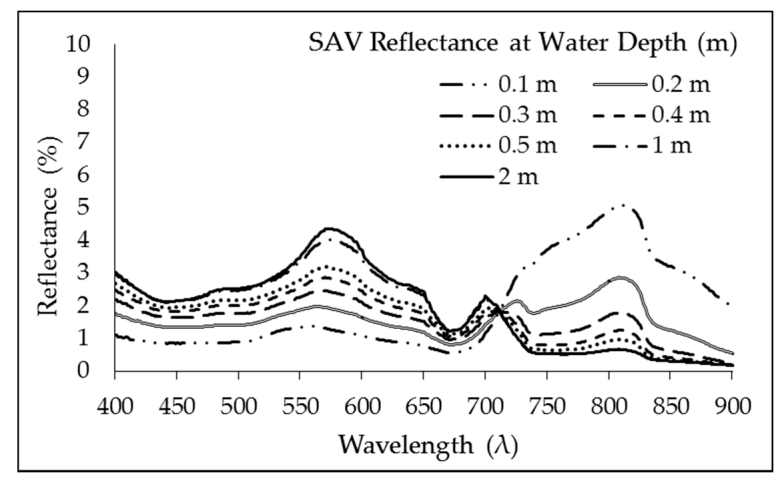

Figure 11. Simulated reflectance spectra of SAV at a varying water depth (0.1 $\mathrm{m}$ to $2 \mathrm{~m})$. 
Considering the shallow south basin of Lake Biwa (i.e., average water depth of $3.5 \mathrm{~m}$, approximately) where most of the bottom surface is occupied by the SAV bed [59], the maximum average SAV stand height recorded was $>3 \mathrm{~m}$ [61]. Therefore, in this study, we assumed that SAV signal influences the water leaving reflectance and that the bottom albedo is mainly from the SAV bed in the basin. In addition, as the detection of the submerged plant in the water also depends on the plant canopy depth from the water surface and the optical depth (i.e., water clarity) [27,37], we included water transparency as an important parameter for SAV biomass estimation. The SAV decomposition coefficient $\left(a_{v}\right)$, obtained from the Spectral Decomposition Algorithm was used as an independent variable to estimate the SAV biomass of the classified SAV pixels. We used regression analysis to establish the relationship between the SAV decomposition coefficient $\left(a_{v}\right)$ and in situ measured SAV biomass $\left(S A V_{b m}\right)$ in September 2014 as well as the water transparency $\left(Z_{W T}\right)$. The biomass model is expressed in Equation (8), which gives an $R^{2}=0.83$ (i.e., using 23 observation points out of 52 in the south basin) significant at $p<0.01$.

$$
S A V_{b m} \times \operatorname{Exp}^{-Z_{W T}}=14.07+504.56 \times a_{v},
$$

where $S A V_{b m}$ indicates the SAV biomass (kg dry weight per pixel); and $Z_{W T}$ is the satellite-derived water transparency. Per pixel biomass was obtained by multiplying the Landsat- 8 image pixel area $(30 \mathrm{~m} \times 30 \mathrm{~m})$ with the observed SAV biomass $\left(\mathrm{kg} \mathrm{DW} \mathrm{m}^{-2}\right)$ of the station.

\section{Results}

\subsection{Satellite-Derived Water Transparency $\left(Z_{W T}\right)$}

Water transparency derived using the satellite image gives a good fit $\left(R^{2}=0.77\right)$ with the in situ measured data (i.e., using 53 validation points) (Figure 12). Water transparency maps were generated (2013-2016) using the Landsat-8 satellite image for the south basin of Lake Biwa (Figure 13). A slight overestimation of water transparency was obtained particularly for the area with water transparency $<1 \mathrm{~m}$ and slight underestimation noted for the areas with water transparency $>3 \mathrm{~m}$.

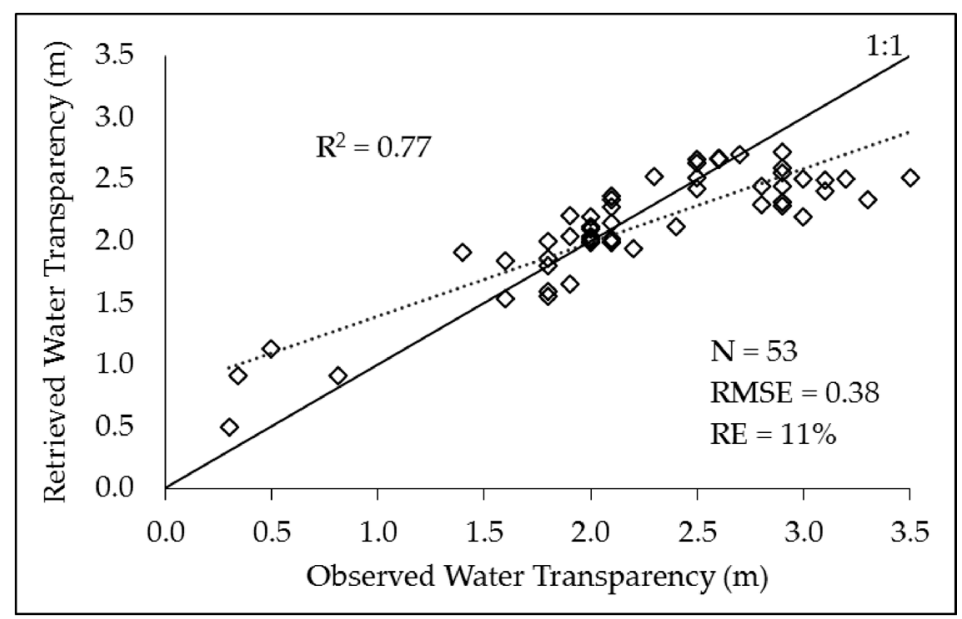

Figure 12. Observed and retrieved (satellite-derived) water transparency in the south basin of Lake Biwa (1 October 2013). N; number of validation points; RMSE: root-mean-square error; RE: relative error.

In 2013, based on the ground truth data, the overall root-mean-square error (RMSE) and absolute error estimated for the 53 validation points in the south basin was $0.38 \mathrm{~m}$ and $0.28 \mathrm{~m}$, respectively. Table 3 shows the accuracy assessment for the range of water transparency derived from the satellite images in the south basin. 

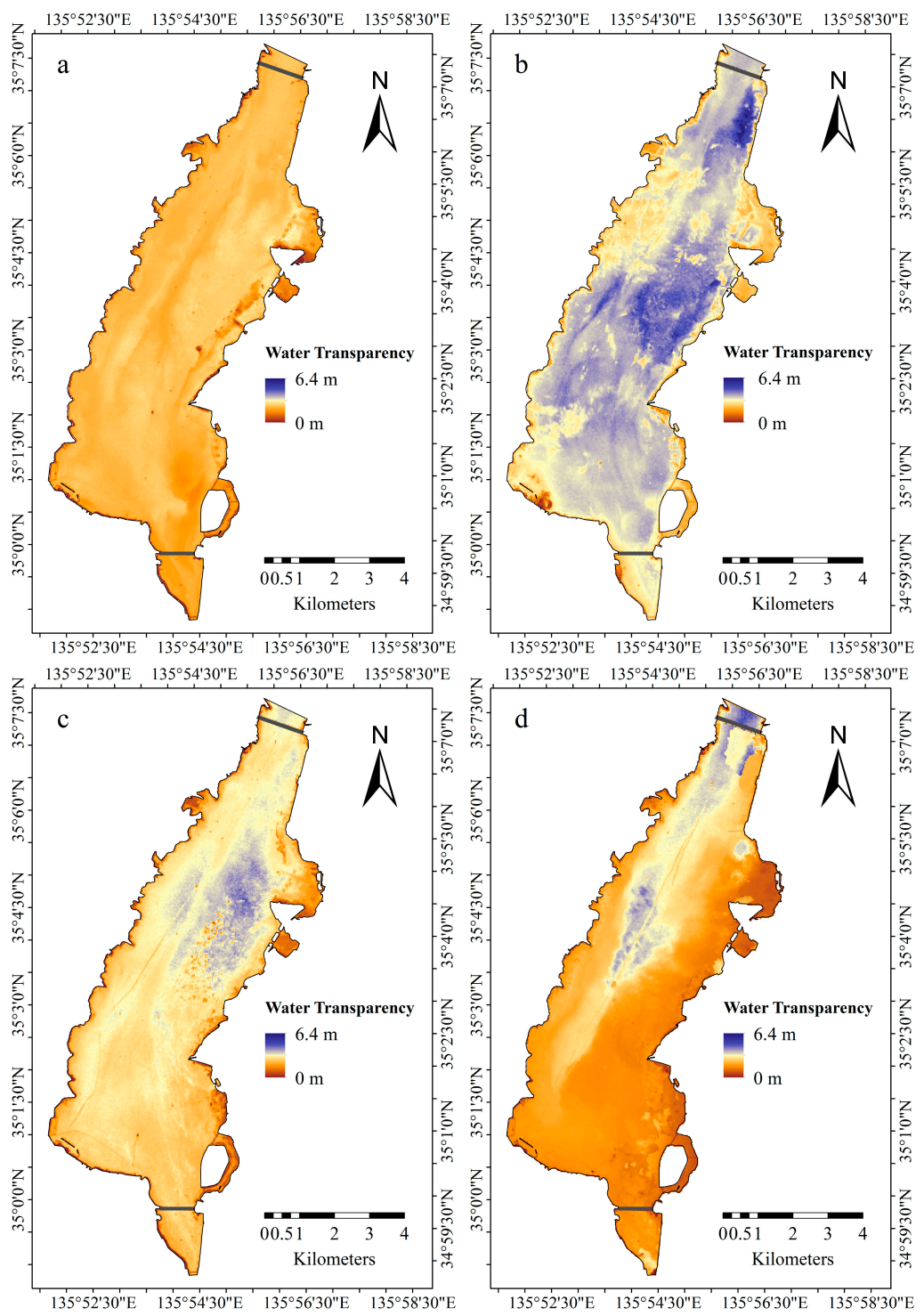

Figure 13. Satellite-derived water transparency map of the south basin of Lake Biwa (2013-2016): (a) October 2013, (b) September 2014, (c) September 2015, and (d) September 2016.

Table 3. Accuracy assessment of satellite-derived water transparency with in situ data (October 2013), for the south basin of Lake Biwa.

\begin{tabular}{cccc}
\hline Water Transparency (m) & RMSE & Absolute Error & N \\
\hline$<1$ & 0.44 & 0.38 & 4 \\
$1-2$ & 0.24 & 0.20 & 11 \\
$2-3$ & 0.25 & 0.19 & 32 \\
$>3$ & 0.77 & 0.75 & 7 \\
\hline
\end{tabular}

Furthermore, we calculated the area with water transparency $\leq 1.5 \mathrm{~m}$, between $>1.5 \mathrm{~m}$ to $<3.0 \mathrm{~m}$, and $\geq 3.0 \mathrm{~m}$. In 2016 and 2013, the area with water transparency $>3.0 \mathrm{~m}$ is only $15 \%\left(8 \mathrm{~km}^{2}\right)$ and $<1 \%$ $\left(1 \mathrm{~km}^{2}\right)$ respectively, whereas in 2014 it is $54 \%\left(28 \mathrm{~km}^{2}\right)$ of the basin area (Table 4). Moreover, the area with water transparency $<1.5 \mathrm{~m}$ increased in $2016\left(14 \mathrm{~km}^{2}\right)$ when compared with the remaining years (only $3 \mathrm{~km}^{2}$ ). Although $92 \%$ of the basin area in 2013 has a water transparency of between $1.5 \mathrm{~m}$ and $3 \mathrm{~m}$, the maximum water transparency retrieved is the lowest $(3.7 \mathrm{~m})$ when compared to 2014 (6.4 m), 2015 (5.1 m), and 2016 (5.5 m). In 2014 and 2015, more than 30\% of the basin area has water 
transparency $>3 \mathrm{~m}$ which indicates a relatively clear water state [62] when compared with other years. A slight overestimation of water transparency was noted, particularly for the area with water transparency $<1 \mathrm{~m}$. However, in almost all the years, reduced water clarity was obtained in two particular conditions, locations with high turbidity, and where the vegetation emerged out of the water surface. The estimated average water transparencies for all years based on 52 stations are $2.2 \mathrm{~m}$ (October 2013), $2.9 \mathrm{~m}$ (September 2014), $2.6 \mathrm{~m}$ (September 2015), and $2.0 \mathrm{~m}$ (September 2016).

Table 4. Satellite-derived water transparency of the south basin of Lake Biwa (2013-2016).

\begin{tabular}{ccccc}
\hline \multirow{2}{*}{ Water Transparency $(\mathbf{m})$} & \multicolumn{4}{c}{ Area $\left(\mathbf{k m}^{\mathbf{2}}\right)$} \\
\cline { 2 - 5 } & $\mathbf{2 0 1 3}$ & $\mathbf{2 0 1 4}$ & $\mathbf{2 0 1 5}$ & $\mathbf{2 0 1 6}$ \\
\hline$\leq 1.5$ & 3 & 3 & 3 & 14 \\
$>1.5$ to $<3.0$ & 48 & 21 & 31 & 30 \\
$\geq 3.0$ & 1 & 28 & 18 & 8 \\
\hline
\end{tabular}

\subsection{SAV Distribution Map}

In $2014,9.6 \mathrm{~km}^{2}$ of the south basin area was infested with SAV, as detected by the Landsat- 8 image. Out of 52 validation points, 45 were classified correctly, resulting in an overall accuracy of $86.5 \%$ and the kappa coefficient of 0.68 . Out of $17 \mathrm{SAV}$ field points, 13 were correctly classified, and three were misclassified as "other" (i.e., clear water, turbid water, emergent and floating vegetation, and other unclassified) which gives the producer an accuracy of $76.5 \%$ and the user an accuracy of $81.3 \%$. The Kappa coefficient relative to the SAV class is 0.74 (Table 5), indicating strong agreement. The SAV field points were selected based on the observed biomass in 2014, water depth, and chlorophyll a concentration. In addition, the locations with chlorophyll a $>20 \mu \mathrm{g} / \mathrm{L}$ along with the site where the SAV biomass $<100 \mathrm{~g} \mathrm{DW} \mathrm{m}^{-2}$ were excluded and not considered as SAV sites.

Table 5. Error matrix produced from the field verification data of September 2014. Of 52 points, 45 were verified as correct $(86.5 \%)$.

\begin{tabular}{|c|c|c|c|c|c|}
\hline \multicolumn{6}{|c|}{ Ground Reference } \\
\hline Map class & SAV & $\begin{array}{c}\text { Other (clear water, } \\
\text { turbid water, emergent } \\
\text { and floating vegetation, } \\
\text { unclassified) }\end{array}$ & Total & $\begin{array}{c}\text { User's accuracy } \\
(\%)\end{array}$ & $\begin{array}{c}\text { Error of } \\
\text { commission }\end{array}$ \\
\hline SAV & 13 & 3 & 16 & 81.3 & 18.8 \\
\hline $\begin{array}{c}\text { Other (clear water, } \\
\text { turbid water, emergent } \\
\text { and floating vegetation, } \\
\text { unclassified) }\end{array}$ & 4 & 32 & 36 & 88.9 & 11.1 \\
\hline Total & 17 & 35 & 52 & & \\
\hline Producer's accuracy (\%) & 76.5 & 91.4 & $\begin{array}{l}\text { Overall } \\
\text { Accuracy }\end{array}$ & & \\
\hline Error of omission & 23.5 & 8.6 & $86.5 \%$ & & \\
\hline
\end{tabular}

Overall kappa Coefficient is 0.68 and Kappa coefficient relative to SAV is 0.74 . Error of Commission: fraction of values that are predicted to be in a class but do not belong to that class (i.e., false positive); Error of Omission: fraction of values that belong to a class but were predicted to be in a different class (i.e., false negative).

In order to assess the SAV classification accuracy for the other images (i.e., 2013, 2015, and 2016), we identified total 17 SAV stations used for validation (i.e., Station 1, 5, 6, 9, 15, 18, 27, 34, 36, 38, 41, $42,43,45,48,49$ and 52) out of 52 observation points (Figure 1) based on the available data in Table 1 and the in situ survey (2016). We also used the SAV biomass maps available in the literature for the south basin of Lake Biwa, primarily for the SAV growth period (i.e., mainly September) in 2002, 2007, 2012, and $2014[63,65]$. Based on the available data information, we selected the stations where the occurrence of SAV was common in the past years, with an SAV biomass $>200 \mathrm{~g} \mathrm{DW} \mathrm{m}^{-2}$. The SAV 
classification accuracy achieved for each image based on the selected stations is 70.5\% (October 2013), 76.4\% (September 2015), and 82.3\% (September 2016), respectively.

The coverage area of SAV detected using the satellite image in the south basin is given in Table 6 .

Table 6. Satellite-derived SAV coverage area in the south basin of Lake Biwa (2013-2016).

\begin{tabular}{ccccc}
\hline Coverage Area $\left(\mathbf{k m}^{\mathbf{2}}\right)$ & $\mathbf{2 0 1 3}$ & $\mathbf{2 0 1 4}$ & $\mathbf{2 0 1 5}$ & $\mathbf{2 0 1 6}$ \\
\hline SAV & 10.65 & 9.61 & 15.65 & 21.04 \\
Other & 41.35 & 42.31 & 36.35 & 29.1 \\
\hline
\end{tabular}

The SAV distribution map generated by the satellite image showed that the detected SAV coverage area increased in recent years, particularly in $2015\left(15.7 \mathrm{~km}^{2}\right)$ and $2016\left(21 \mathrm{~km}^{2}\right)$ (Figure 14). The maximum water transparency at which SAV was detected in the south basin was $2.2 \mathrm{~m}, 3.7 \mathrm{~m}, 3.0 \mathrm{~m}$ and $3.1 \mathrm{~m}$ in 2013, 2014, 2015 and 2016, respectively. With the increase in transparency, the maximum water depth at which the SAV was detected increased to the water depth of $5.6 \mathrm{~m}$ and $4.9 \mathrm{~m}$ in the 2014 and 2015 when compared to $4.4 \mathrm{~m}$ and $4.3 \mathrm{~m}$ in 2013 and 2016, individually. Mostly, the SAV occurrence in the eastern and northeastern shoreline was more frequent. However, in 2016 the distribution of SAV spread towards the west and the northeast side of the south basin.
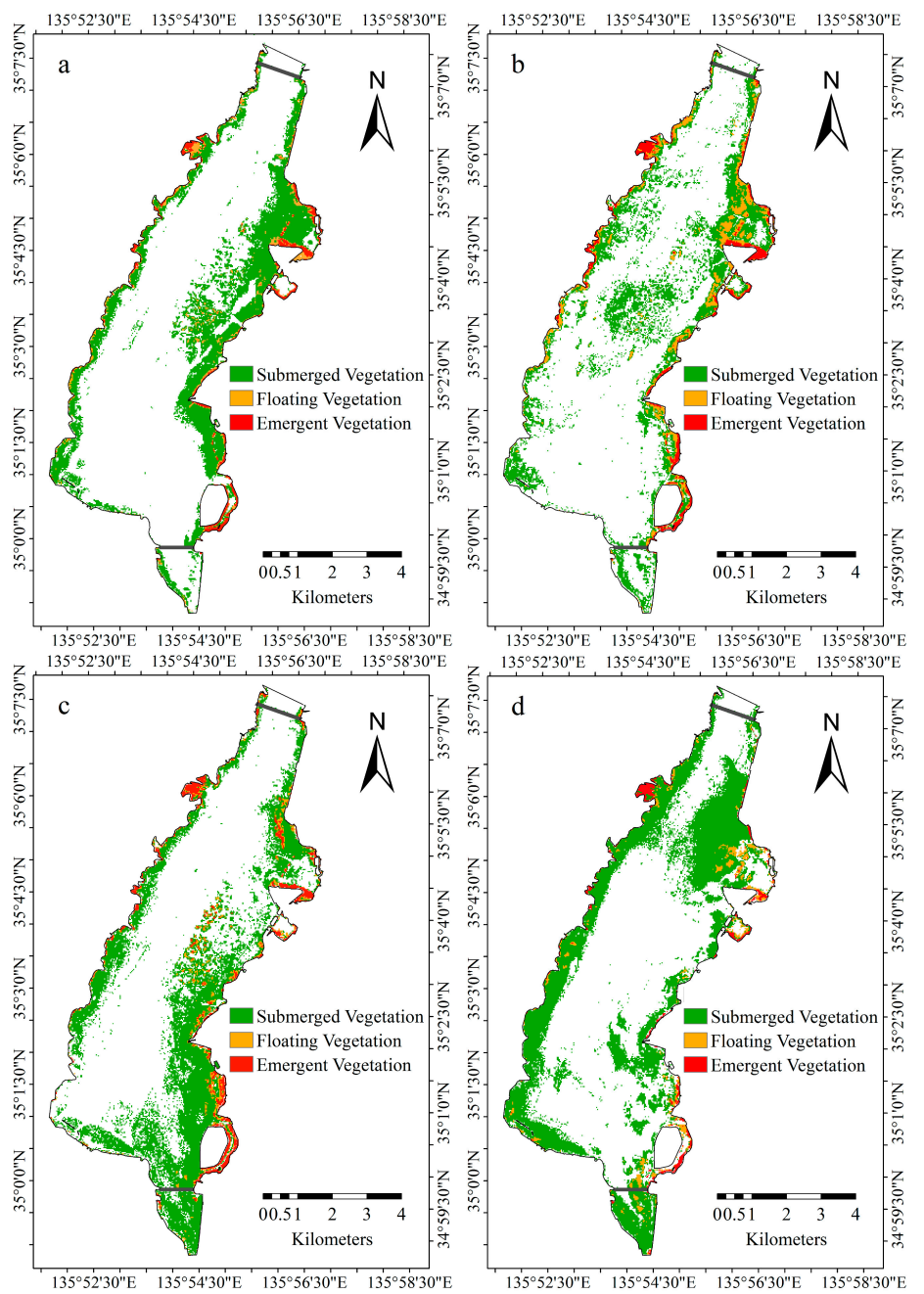

Figure 14. SAV distribution map of the south basin of Lake Biwa (2013-2016): (a) October 2013, (b) September 2014, (c) September 2015, and (d) September 2016. 


\section{3. $S A V$ Biomass}

Out of 52 observation locations, we used 17 SAV classified locations (i.e., September 2014) for the validation (Figure 15). The result shows good agreement, with overall $\mathrm{R}^{2}$ of 0.79 . The SAV biomass maps are displayed in Figure 16.

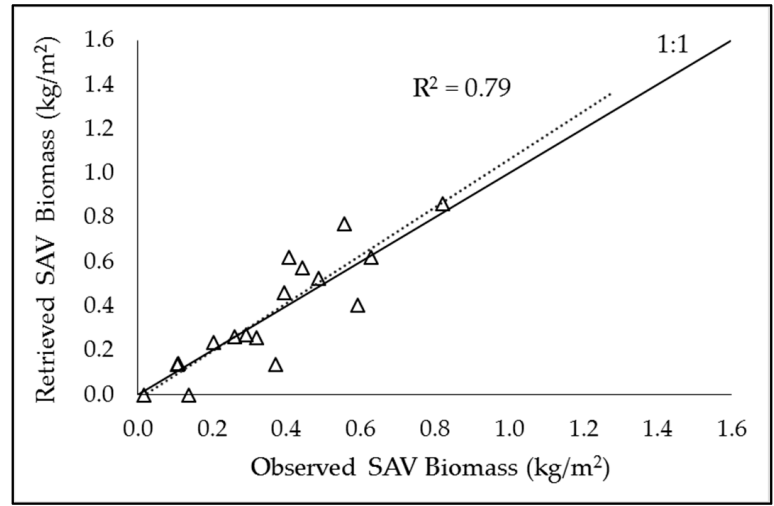

Figure 15. Estimated and in situ measured SAV Biomass (September 2014) in the south basin of Lake Biwa.
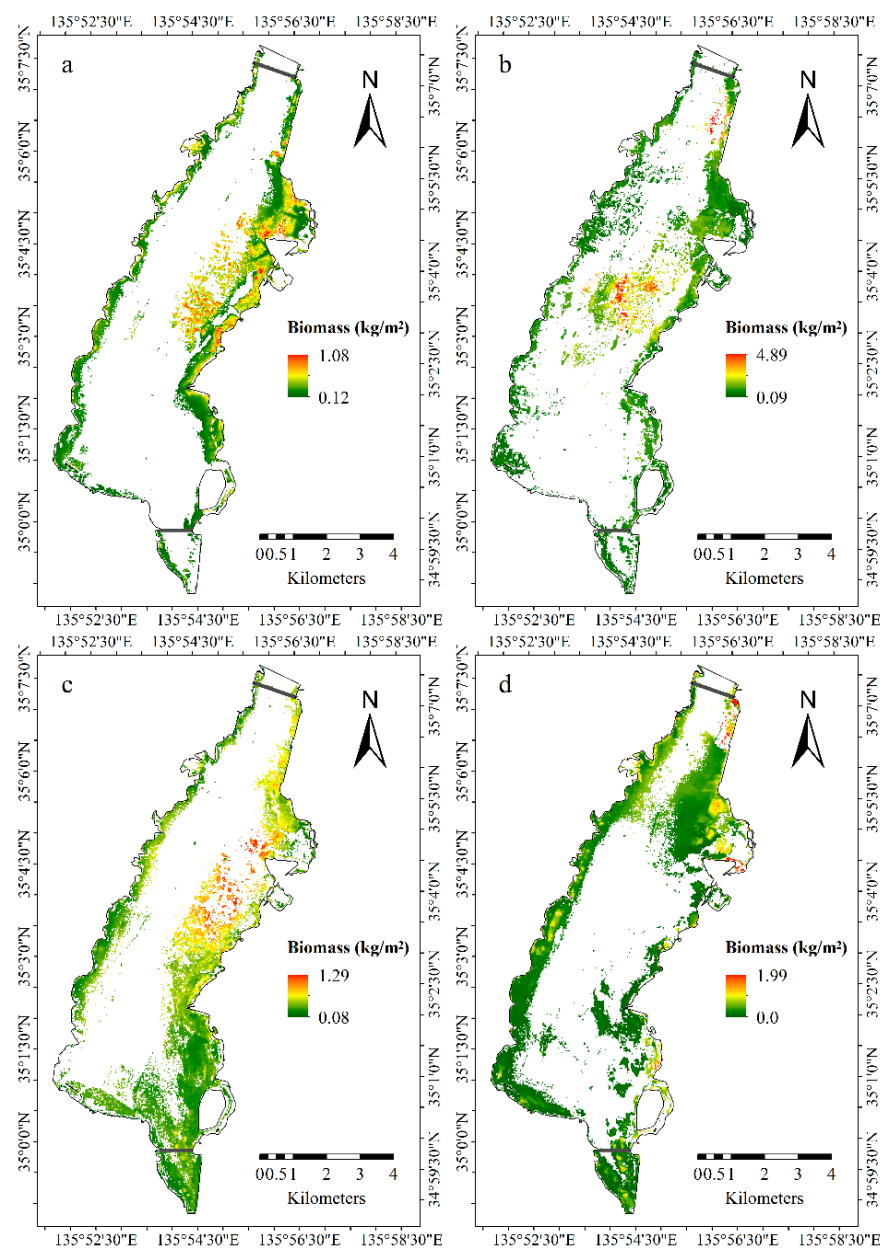

Figure 16. Satellite-derived biomass map $\left(\mathrm{kg} \mathrm{DW} \mathrm{m}^{-2}\right)$ of SAV and floating vegetation in the south basin of Lake Biwa (2013-2016): (a) October 2013, (b) September 2014, (c) September 2015, and (d) September 2016. 
The total RMSE and mean absolute error (in 2014) obtained for the 17 SAV classified stations is $0.26 \mathrm{~kg} \mathrm{DW} \mathrm{m}^{-2}$ and $0.21 \mathrm{~kg} \mathrm{DW} \mathrm{m}^{-2}$, respectively (Table 7). The minimum and maximum absolute errors are $0.172 \mathrm{~kg} \mathrm{DW} \mathrm{m}^{-2}$ and $0.723 \mathrm{~kg} \mathrm{DW} \mathrm{m}^{-2}$, respectively. In 2016, the overall RMSE obtained for the surveyed locations in the south basin was $0.28 \mathrm{~kg} \mathrm{DW} \mathrm{m}^{-2}$, with a mean absolute error of $0.20 \mathrm{~kg} \mathrm{DW} \mathrm{m}^{-2}$, whereas the minimum and maximum absolute errors are $0.013 \mathrm{~kg} \mathrm{DW} \mathrm{m}^{-2}$ and $0.667 \mathrm{~kg} \mathrm{DW} \mathrm{m}^{-2}$, respectively. On the other hand, the total biomass estimation errors obtained in 2014 and 2016 based on the SAV classified stations are approximately $968 \mathrm{~kg} \mathrm{DW} \mathrm{m}^{-2}(1.0 \mathrm{t})$ and $332 \mathrm{~kg}$ DW $(0.332 \mathrm{t})$, respectively.

Table 7. Estimated RMSE of SAV biomass for the classified stations (September 2014).

\begin{tabular}{|c|c|c|}
\hline \multirow{2}{*}{ Biomass Range (kg DW m ${ }^{-2}$ ) } & \multicolumn{2}{|c|}{17 SAV Classified Stations } \\
\hline & RMSE & $\mathbf{N}$ \\
\hline $0-0.1$ & 0.17 & 1 \\
\hline $0.1-0.3$ & 0.30 & 6 \\
\hline $0.3-0.5$ & 0.20 & 6 \\
\hline $0.5-0.7$ & 0.20 & 2 \\
\hline $0.7-1.0$ & 0.33 & 2 \\
\hline $1.0-1.4$ & - & 0 \\
\hline Overall RMSE & 0.26 & \\
\hline Mean Absolute Error & 0.21 & \\
\hline
\end{tabular}

The total SAV biomass estimated for the classified area in the south basin is $3390 \mathrm{t}, 3919 \mathrm{t}, 5242 \mathrm{t}$ and 4550 t dry weight for 2013, 2014, 2015 and 2016, respectively (Table 8). In 2015, the estimated total biomass for the SAV detected area was 55\% (1852 t) more than the biomass in 2013. It was 34\% (1160 t) and 16\% (529 t) more in 2014 and 2016, respectively. Despite an amplified total SAV biomass in 2015, the maximum biomass density is comparatively lower $\left(1.29 \mathrm{~kg} \mathrm{DW} \mathrm{m}^{-2}\right)$ than in $2014(4.89 \mathrm{~kg}$ DW $\mathrm{m}^{-2}$ ) and $2016\left(1.99 \mathrm{~kg} \mathrm{DW} \mathrm{m}^{-2}\right)$, which could be the effect of changing water clarity in the south basin.

Table 8. Estimated SAV biomass in the south basin of Lake Biwa using the Spectral Decomposition Algorithm for October 2013, and September 2014, 2015, 2016.

\begin{tabular}{ccccc}
\hline & $\mathbf{2 0 1 3}$ & $\mathbf{2 0 1 4}$ & $\mathbf{2 0 1 5}$ & $\mathbf{2 0 1 6}$ \\
\hline Average vegetation biomass $\left(\mathrm{kg} \mathrm{DW} \mathrm{m}^{-2}\right)$ & 0.335 & 0.440 & 0.351 & 0.238 \\
Average SAV biomass $\left(\mathrm{kg} \mathrm{DW} \mathrm{m}^{-2}\right)$ & 0.318 & 0.408 & 0.335 & 0.216 \\
Total vegetation coverage area $\left(\mathrm{km}^{2}\right)$ & 15.5 & 13.4 & 18.6 & 22.9 \\
Total SAV coverage area $\left(\mathrm{km}^{2}\right)$ & 10.7 & 9.6 & 15.7 & 21.0 \\
Total vegetation biomass $(\mathrm{t})$ & 5193 & 5872 & 6530 & 5451 \\
Total SAV biomass $(\mathrm{t})$ & 3390 & 3919 & 5242 & 4550 \\
\hline
\end{tabular}

Average vegetation biomass is the average of all the stations in the south basin classified as SAV.

\section{Discussion}

In optically shallow lakes, high turbidity significantly affects the spectral detection of SAV by reducing the water clarity $[38,45]$. Additionally, healthy vegetation growth often related to the water clarity in an aquatic system [10,11]. Therefore, in this study water clarity (i.e., water transparency) is considered as an important parameter for SAV abundance mapping. However, obtaining water transparency data for each year and location which can coincide with the satellite overpass time is not possible every time. Therefore, we applied a water transparency retrieval algorithm to the Landsat- 8 image in order to generate the water clarity map for the SAV growth period in the south basin of Lake Biwa. Conversely, due to the time difference of \pm 5 days in the observed water transparency data and the Landsat-8 image acquisition time, a good agreement between the observed and satellite-derived 
water transparency was not expected (the obtained $\mathrm{R}^{2}$ is 0.77 ). In the south basin of Lake Biwa, the amplified SAV growth is considered as a key driving factor for improved water clarity [22,61]. In this study, the mapped SAV coverage area does not rise as expected, with increased water clarity for the same year. For instance, water clarity obtained in 2014 is higher than 2013, 2015, and 2016, while the detected SAV area is rather low $\left(9.6 \mathrm{~km}^{2}\right)$, in the same year (Figures 13 and 14). It could be attributed to the fact that aquatic macrophyte reacts slowly and progressively (i.e., in years) to the changes in aquatic systems (such as nutrient conditions and turbidity), in contrast to phytoplankton and other microalgae [70]. Principally, in lakes with increasing eutrophication, SAV communities often show a considerable delay response time [1]. However, another factor such as SAV stand height could simultaneously contribute to its low detection [64]. In Lake Biwa, SAV stand height tends to increase at the water depth of 4-6 m and decrease in relatively shallow turbid water areas [61]. Therefore, if the water is relatively turbid in the shallow basin even with an extensive SAV bed of short growing species, the detection of SAV is restricted using the satellite image. Moreover, in deep water, if the stand height of SAV is not within the optical depth limit the detection of SAV is not possible using the satellite image [8]. Consequently, an increased SAV distribution can be seen in the following year of $2015\left(15.7 \mathrm{~km}^{2}\right)$ and $2016\left(21.0 \mathrm{~km}^{2}\right)$, in this study (Table 6).

Based on the previous studies $[59,61]$ on the south basin of Lake Biwa, we assumed that $>90 \%$ of the basin area has SAV as the bottom surface. However, the detected SAV coverage area in this study is $18 \%$ to $40 \%$ (i.e., minimum to maximum detection from all four images (2013-2016)). The pixels classified as SAV are located mainly in the near shore areas of the basin. This indicates the limitation of the classification approach used in this study, which can classify the SAV mainly in the low water depth area (or with the low canopy depth). Several factors may contribute to the low detection, such as increased eutrophication, SAV stand height, and deep water areas (the maximum water depth in south basin is $8 \mathrm{~m}$ ). In some studies [36], the result showed that in clear water the SAV could easily be detected at a 1-m canopy depth (the water column depth from the water surface to the top of the SAV canopy). However, with the increase in turbidity the detection reduces to a maximum canopy depth of $0.46 \mathrm{~m}$ to $0.5 \mathrm{~m}$. The result further suggests that increased turbidity significantly affects SAV detection. With increased water level in Lake Biwa, it is not possible to detect all the SAV (i.e., canopy depth increases) [22]. In the south basin, based on the in situ survey and previous studies [61], we found that SAV stand height varies (i.e., $<0.2 \mathrm{~m}$ to $>3 \mathrm{~m}$ ) with location and water depth. It could also be the reason for the variation in the SAV detection rate in this study. For instance, SAV could not be detected at a location surveyed in September 2016 (i.e., pixel circled next to station 50 in Figure 1), where the observed SAV coverage is $95 \%$ (diver survey). The estimated SAV canopy depth at the same location was between $3.2 \mathrm{~m}$ and $4.3 \mathrm{~m}$ (i.e., subtracting observed water depth $5.1 \mathrm{~m}$ and SAV stand height $0.76 \mathrm{~m}$ to $1.9 \mathrm{~m}$ ). Similar is the case with the location circled next to station 26 , with an SAV canopy depth from $2.6 \mathrm{~m}$ to $3.6 \mathrm{~m}$ (i.e., water depth $4.2 \mathrm{~m}$, SAV stand height $0.6-1.6 \mathrm{~m}$, SAV coverage $68 \%$ ), where SAV could not be detected. Furthermore, the discrimination and identification of submerged vegetation become more difficult with the increase in water depth as the proportion of reflectance reaching the remote sensing device, diminishes with water depth [71]. Thus, apart from coverage area, the SAV canopy depth is also an important factor which substantially affects the detection of SAV. In previous studies, the seagrass of a coastal zone was mapped with an accuracy of only $59 \%$ by multispectral imagery (i.e., Landsat) whereas the high accuracy of $85-90 \%$ was obtained using the hyperspectral images (such as IKONOS and CASI) [71,72]. This further indicates the limitation of mapping deep water SAV species using the multispectral image which offers the information in 4- 8 broad spectral bands compared to the hyperspectral images which provide the information at many more narrow spectral wavelengths, located around typical absorption points [71].

The new Spectral Decomposition Algorithm was developed and applied to determine the SAV biomass for the south basin. Each decomposition coefficient in the algorithm holds the mass information of each endmember, and they were used independently in the estimation model (SAV biomass model). Therefore, compared to the conventional models, this approach is less 
sensitive to geographical and temporal variability. If the standard reflectance spectra of the respective endmember remain consistent with similar spectral sensitivity, this model could be applied to other satellite images [51,73]. The new model is capable of estimating the SAV biomass for the whole lake basin. To avoid any confusion with other mixed pixels, we applied the biomass model to the SAV classified pixels in the satellite image. Because the technique applies to the classified SAV pixels only, the low detection of SAV may affect the total biomass estimation of the basin. Conversely, when the deep water SAV can also be detected, the biomass model can successfully determine the total biomass. Thus, there is a need for a classification approach which can detect the deep water SAV.

In 2014, the SAV coverage area was comparatively lower than in other years. Conversely, the maximum biomass density is substantially higher $\left(4.89 \mathrm{~kg} \mathrm{DW} \mathrm{m}^{-2}\right)$ in the same year. It could be the result of improved water clarity, which allowed sufficient light penetration. Light is predominantly an important environmental factor regulating SAV growth [55], which is directly affected by the transparency, depth of plant growth, and shading from other plants. Noticeably high total SAV biomass was estimated for 2015 and 2016, following the clear water year (2014). In some instances, the eutrophication or invasive aquatic species results in excessive growth of the SAV biomass, mainly in locations where previously nutrient levels did not support the extensive SAV growth $[3,48,55]$.

Distinguishing aquatic vegetation from the other sources of confusion, such as deep water and turbid water is an essential step before mapping SAV in eutrophic lakes. The prior knowledge of water depth and transparency helps to detect and classify aquatic vegetation from turbid water areas. Nevertheless, SAV detection in inland waters is often restricted by meteorological (i.e., weather condition, cloud cover, the sun, wind speed, view angle), physical (i.e., water depth, wave action), and biological (i.e., phenology of plant species) heterogeneity $[4,16,20,27,35,74]$. Furthermore, the apparent optical properties (i.e., surface reflectance and diffuse attenuation) and inherent optical properties (i.e., absorption and scattering) of water largely affects the SAV detection in the water bodies $[31,55,74]$. Even in a pixel with $100 \%$ SAV cover, its reflectance is still dominated by absorption of water [16]. In Lake Biwa, SAV species often grow in clusters. Therefore, it is hard to find a pure pixel representing a single SAV species in a medium resolution image $(30 \mathrm{~m} \times 30 \mathrm{~m})$ thus the species level classification could not be performed.

\section{Conclusions}

We tested the applicability of multispectral Landsat- 8 satellite image to map the distribution and biomass of the submerged aquatic vegetation (SAV)-infested area in the eutrophic shallow basin of Lake Biwa. The new biomass estimation model was successfully applied to the SAV-classified area. The study shows that water clarity is important for SAV detection and biomass estimation using satellite remote sensing for shallow lakes. However, long-term monitoring (i.e., monthly or seasonally) is essential to accurately understanding the influence of water clarity on the growth and distribution of SAV in a eutrophic water body. Apart from water conditions and depth, the SAV stand height in the lake also influences the detection of SAV. The estimated biomass density was significantly high for 2014, with high water transparency. An upsurge in SAV biomass to 16\% (2014), 55\% (2015), and 34\% (2016), was noted when compared to the biomass in 2013. The technique provides a biomass estimate that is consistent with the in situ measurements. The satellite-derived results suggest that SAV growth is significantly influenced by the water quality conditions, in the eutrophic basin. However, the changes may not occur immediately but are more visible in the following years.

The limitation of the developed approach is mainly associated with the low detection of SAV (i.e., using SAV classification method) and inadequate ground truth data (i.e., limited field data matching with the satellite image acquisition time). Adequate field data which also coincides with the satellite-overpass time is essential to developing a robust satellite-based model with good agreement, to be applied to other satellite images. In addition, the SAV biomass model also depends on the water transparency data of the lake. Thus, it is essential to have an accurate water clarity information for the respective water body. For detailed SAV species studies, the application of medium resolution satellite 
images may not be very feasible with limited in situ field data information. Furthermore, with the appropriate information of the potential endmembers (i.e., based on the water condition of the lake), their respective standard reflectance spectra, and with the sufficient water transparency data of the lake, the developed method could be tested on other shallow lakes for SAV biomass estimation.

The Landsat-8 image was successfully utilized for SAV abundance mapping in the eutrophic basin of the large lake. The application of the satellite-based technique to assess the SAV distribution and biomass will be useful for the lake water managers and concerned stakeholders, for frequent monitoring, and to decide effective management activity and remediation efforts for maintaining a healthy lake ecosystem.

Acknowledgments: The research was financially supported by the Integrated Research Program for Advancing Climate Models (TOUGOU program) and Program for Risk Information on Climate Change (SOUSEI Program) under the Ministry of Education, Culture, Sports, Science, and Technology-Japan (MEXT). We are particularly grateful to Lake Biwa Environmental Research Institute, Otsu (LBERI), Japan Water Agency (JWA), and Japan Meteorological Agency (JMA). Field data collection would not be possible without their generous help. We also thanks to the editor and the reviewers for their constructive comments and valuable suggestions, which improved the quality of this paper.

Author Contributions: Shweta Yadav is the primary author of this manuscript, conducted much of the field research as well as laboratory experiments, analyzed the imagery, developed the model, created the maps and summarized the results. Yosuke Yamashiki led the research, and conducted much of the field research. Minoru Yoneda, Junichi Susaki, and Yosuke Yamashiki significantly contributed to the research, gave directions and guided the research activities, and provided editorial comments on the manuscript.

Conflicts of Interest: The authors declare no conflict of interest.

\section{References}

1. Søndergaard, M.; Johansson, L.S.; Lauridsen, T.L. Submerged macrophytes as indicators of the ecological quality of lakes. Freshw. Biol. 2010, 55, 893-908. [CrossRef]

2. Scheffer, M.; Carpenter, S.; Foley, J.A.; Folke, C.; Walker, B. Catastrophic shifts in ecosystems. Nature 2001, 413, 591-596. [CrossRef] [PubMed]

3. Boyd, C.E.; Carolina, S. The limnological role of aquatic macrophytes and their relationship to reservoir management. Reserv. Fish. Limnol. 1971, 153-166.

4. Carpenter, S.R.; Lodge, D.M. Effects of submersed macrophytes on ecosystem processes. Aquat. Bot. 1986, 26, 341-370. [CrossRef]

5. Santos, M.J.; Anderson, L.W.; Ustin, S.L. Effects of invasive species on plant communities: An example using submersed aquatic plants at the regional scale. Biol. Invasions 2011, 13, 443-457. [CrossRef]

6. Lovell, S.J.; Stone, S.F.; Fernandez, L. The economic impacts of aquatic invasive species: A review of the literature. Agric. Resour. Econ. Rev. 2006, 35, 195-208. [CrossRef]

7. Verhofstad, M.J.; Bakker, E.S. Classifying nuisance submerged vegetation depending on ecosystem services. Limnology 2017. [CrossRef]

8. Brooks, C.; Grimm, A.; Shuchman, R.; Sayers, M.; Jessee, N. Remote Sensing of Environment A satellite-based multi-temporal assessment of the extent of nuisance Cladophora and related submerged aquatic vegetation for the Laurentian Great Lakes. Remote Sens. Environ. 2015, 157, 58-71. [CrossRef]

9. Zehnsdorf, A.; Hussner, A.; Eismann, F.; Rönicke, H. Limnologica Management options of invasive Elodea nuttallii and Elodea canadensis. Limnologica 2015, 51, 110-117. [CrossRef]

10. Scheffer, M.; Jeppesen, E. Alternative stables states. In The Structuring Role of Submerged Macrophytes in Lakes; Jeppesen, E., Søndergaard, M., Søndergaard, M., Christoffersen, K., Eds.; Springer: New York, NY, USA, 1998; pp. 397-406.

11. Takamura, N.; Kadono, Y.; Fukushima, M.; Nakagawa, M.; Kim, B. Effects of aquatic macrophytes on water quality and phytoplankton communities in shallow lakes. Ecol. Res. 2003, 18, 381-395. [CrossRef]

12. Van Donk, E.; Van de Bund, W.J. Impact of submerged macrophytes including charophytes on phyto- and zooplankton communities: Allelopathy versus other mechanisms. Aquat. Bot. 2002, 72, 261-274. [CrossRef]

13. Mulderij, G.; Van Nes, E.H.; Van Donk, E. Macrophyte-phytoplankton interactions: The relative importance of allelopathy versus other factors. Ecol. Model. 2007, 204, 85-92. [CrossRef] 
14. Pan, G.; Yang, B.; Wang, D.; Chen, H.; Tian, B.; Zhang, M.L.; Yuan, X.Z.; Chen, J. In-lake algal bloom removal and submerged vegetation restoration using modified local soils. Ecol. Eng. 2011, 37, 302-308. [CrossRef]

15. Zhang, S.Y.; Liu, A.F.; Ma, J.M.; Zhou, Q.H.; Xu, D.; Cheng, S.P.; Zhao, Q.; Wu, Z. Bin Changes in physicochemical and biological factors during regime shifts in a restoration demonstration of macrophytes in a small hypereutrophic Chinese lake. Ecol. Eng. 2010, 36, 1611-1619. [CrossRef]

16. Hestir, E.L.; Khanna, S.; Andrew, M.E.; Santos, M.J.; Viers, J.H.; Greenberg, J.A.; Rajapakse, S.S.; Ustin, S.L. Identification of invasive vegetation using hyperspectral remote sensing in the California Delta ecosystem. Remote Sens. Environ. 2008, 112, 4034-4047. [CrossRef]

17. Kadono, Y. Alien aquatic plants naturalized in Japan: History and present status. Glob. Environ. Res. 2004, 8, 163-169.

18. Yarrow, M.; Marín, V.H.; Finlayson, M.; Tironi, A.; Delgado, L.E.; Fischer, F. The ecology of egeria densa planchon (liliopsida: Alismatales): A wetland ecosystem engineer. Rev. Chil. Hist. Nat. 2009, 82, 299-313. [CrossRef]

19. Luo, J.; Li, X.; Ma, R.; Li, F.; Duan, H.; Hu, W.; Qin, B.; Huang, W. Applying remote sensing techniques to monitoring seasonal and interannual changes of aquatic vegetation in Taihu Lake, China. Ecol. Indic. 2016, 60, 503-513. [CrossRef]

20. Nelson, S.A.C.; Cheruvelil, K.S.; Soranno, P.A. Satellite remote sensing of freshwater macrophytes and the influence of water clarity. Aquat. Bot. 2006, 85, 289-298. [CrossRef]

21. Zhang, Y.; Liu, X.; Qin, B.; Shi, K.; Deng, J.; Zhou, Y. Aquatic vegetation in response to increased eutrophication and degraded light climate in Eastern Lake Taihu: Implications for lake ecological restoration. Sci. Rep. 2016, 6, 23867. [CrossRef] [PubMed]

22. Hamabata, E.; Kobayashi, Y. Present status of submerged macrophyte growth in Lake Biwa: Recent recovery following a summer decline in the water level. Lakes Reserv. Res. Manag. 2002, 7, 331-338. [CrossRef]

23. Pinnel, N. A Method for Mapping Submerged Macrophytes in Lakes Using Hyperspectral Remote Sensing; Technical University of Munich: Munich, Germany, 2007.

24. Güttler, F.N.; Niculescu, S.; Gohin, F. Turbidity retrieval and monitoring of Danube Delta waters using multisensor optical remote sensing data: An integrated view from the delta plain lakes to the western-northwestern Black Sea coastal zone. Remote Sens. Environ. 2013, 132, 86-101. [CrossRef]

25. Pacheco, A.; Horta, J.; Loureiro, C. Ferreira Retrieval of nearshore bathymetry from Landsat 8 images: A tool for coastal monitoring in shallow waters. Remote Sens. Environ. 2015, 159, 102-116. [CrossRef]

26. Shuchman, R.A.; Sayers, M.J.; Brooks, C.N. Mapping and monitoring the extent of submerged aquatic vegetation in the laurentian great lakes with multi-scale satellite remote sensing. J. Great Lakes Res. 2013, 39, 78-89. [CrossRef]

27. Silva, T.S.F.; Costa, M.P.F.; Melack, J.M.; Novo, E.M.L.M. Remote sensing of aquatic vegetation: Theory and applications. Environ. Monit. Assess. 2008, 140, 131-145. [CrossRef] [PubMed]

28. Williams, D.; Rybicki, N.; Lombana, A.; O’Brien, T.; Gomez, R. Preliminary investigation of submarged aquatic vegetation mapping usingyperspectral remote sensing. Environ. Monit. Assess. 2003, 81, 383-392. [CrossRef]

29. Underwood, E.; Ustin, S.; DiPietro, D. Mapping nonnative plants using hyperspectral imagery. Remote Sens. Environ. 2003, 86, 150-161. [CrossRef]

30. Ackleson, S.G.; Klemas, V. Remote sensing of submerged aquatic vegetation in lower chesapeake bay: A comparison of Landsat MSS to TM imagery. Remote Sens. Environ. 1987, 22, 235-248. [CrossRef]

31. Mobley, C.D. Radiative transfer in the ocean. Encycl. Ocean Sci. Second Ed. 2008, 619-628. [CrossRef]

32. Reinart, A.; Paavel, B.; Tuvikene, L. Effect of coloured dissolved organic matter on the attenuation of photosynthetically active radiation in Lake Peipsi. Proc. Estonian Acad. Sci. Biol. Ecol. 2004, 53, 88-105.

33. Sogandares, F.M.; Fry, E.S. Absorption spectrum (340-640 nm) of pure water. Appl. Opt. 1997, 36, 8699-8709. [CrossRef] [PubMed]

34. Sváb, E.; Tyler, A.N.; Preston, T.; Présing, M.; Balogh, K.V. Characterizing the spectral reflectance of algae in lake waters with high suspended sediment concentrations. Int. J. Remote Sens. 2005, 26, 919-928. [CrossRef]

35. Zou, W.; Yuan, L.; Zhang, L. Analyzing the spectral response of submerged aquatic vegetation in a eutrophic lake, Shanghai, China. Ecol. Eng. 2013, 57, 65-71. [CrossRef] 
36. Watanabe, F.S.Y.; Imai, N.N.; Alcântara, E.H.; Rotta, L.H.D.S.; Utsumi, A.G. Signal classification of submerged aquatic vegetation based on the hemispherical-conical reflectance factor spectrum shape in the Yellow and Reg Regions. Remote Sens. 2013, 5, 1856-1874. [CrossRef]

37. Ma, R.; Duan, H.; Gu, X.; Zhang, S. Detecting aquatic vegetation changes in Taihu Lake, China using Multi-temporal Satellite Imagery. Sensors 2008, 8, 3988-4005. [CrossRef] [PubMed]

38. Gholizadeh, M.H.; Melesse, A.M.; Reddi1, L. A comprehensive review on water quality parameters estimation using remote sensing techniques. Sensors 2016, 16, 1298. [CrossRef] [PubMed]

39. Knight, J.F.; Voth, M.L. Application of MODIS imagery for intra-annual water clarity assessment of minnesota lakes. Remote Sens. 2012, 4, 2181-2198. [CrossRef]

40. Oyama, Y.; Matsushita, B.; Fukushima, T. Distinguishing surface cyanobacterial blooms and aquatic macrophytes using Landsat/TM and ETM + shortwave infrared bands. Remote Sens. Environ. 2015, 157, 35-47. [CrossRef]

41. Villa, P.; Mousivand, A.; Bresciani, M. Aquatic vegetation indices assessment through radiative transfer modeling and linear mixture simulation. Int. J. Appl. Earth Obs. Geoinf. 2014, 30, 113-127. [CrossRef]

42. Heege, T.; Bogner, A.; Pinnel, N.; Bostater, C.R.; Santoleri, R. Mapping of submerged aquatic vegetation with a physically based process chain. Remote Sens. Ocean Sea Ice 2003 2004, 5233, 43-50.

43. Jiang, H.; Zhao, D.; Cai, Y.; An, S. A method for application of classification tree models to map aquatic vegetation using remotely sensed images from different sensors and dates. Sensors 2012, 12, 12437-12454. [CrossRef]

44. Hestir, E.L.; Greenberg, J.A.; Ustin, S.L. Classification trees for aquatic vegetation community prediction using imaging spectroscopy. IEEE J. Sel. Top. Appl. Earth Obs. Remote Sens. 2012, 5, 1572-1584. [CrossRef]

45. Karabulut, O.; Akyurek, Z.; Beklioglu, M. Identification and mapping of submerged plants in a shallow lake using quickbird satellite data. J. Environ. Manag. 2009, 90, 2138-2143.

46. Kruse, F.A.; Lefkoff, A.B.; Boardman, J.W.; Heidebrecht, K.B.; Shapiro, A.T.; Barloon, P.J.; Goetz, A.F.H. The spectral image processing system (SIPS) —Interactive visualization and analysis of imaging spectrometer data. Remote Sens. Environ. 1993, 44, 145-163. [CrossRef]

47. Goodwin, N.; Coops, N.C.; Stone, C. Assessing plantation canopy condition from airborne imagery using spectral mixture analysis and fractional abundances. Int. J. Appl. Earth Obs. Geoinf. 2005, 7, 11-28. [CrossRef]

48. Madsen, J.D. Biomass techniques for monitoring and assessing control of aquatic vegetation. Lake Reserv. Manag. 1993, 7, 141-154. [CrossRef]

49. Armstrong, R.A. Remote sensing of submerged vegetation canopies for biomass estimation. Int. J. Remote Sens. 1993, 14, 621-627. [CrossRef]

50. Duarte, C.M.; Kalff, J. Biomass density and the relationship between submerged macrophyte biomass and plant growth form. Hydrobiologia 1990, 196, 17-23. [CrossRef]

51. Oyama, Y.; Matsushita, B.; Fukushima, T.; Matsushige, K.; Imai, A. Application of spectral decomposition algorithm for mapping water quality in a turbid lake (Lake Kasumigaura, Japan) from Landsat TM data. ISPRS J. Photogramm. Remote Sens. 2009, 64, 73-85. [CrossRef]

52. Oyama, Y.; Matsushita, B.; Fukushima, T.; Nagai, T.; Imai, A. A new algorithm for estimating chlorophyll-a concentration from multi-spectral satellite data in case II waters: A simulation based on a controlled laboratory experiment. Int. J. Remote Sens. 2007, 28, 1437-1453. [CrossRef]

53. Lee, Z.; Carder, K.L.; Mobley, C.D.; Steward, R.G.; Patch, J.S. Hyperspectral remote sensing for shallow waters. I. A semianalytical model. Appl. Opt. 1998, 37, 6329-6338. [CrossRef] [PubMed]

54. Mumby, P.J.; Green, E.P.; Edwards, A.J.; Clark, C.D. Measurement of seagrass standing crop using satellite and digital airborne remote sensing. Mar. Ecol. Prog. Ser. 1997, 159, 51-60. [CrossRef]

55. Kirk, J.T.O. Light and Photosynthesis in Aquatic Ecosystems, 3rd ed.; Cambridge University Press: Cambridge, UK, 2011.

56. Lyzenga, D.R. Passive remote sensing techniques for mapping water depth and bottom features. Appl. Opt. 1978, 17, 379. [CrossRef] [PubMed]

57. Nishino, M. Biodiversity of Lake Biwa. In Lake Biwa: Interactions between Nature and People; Kawanabe, H., Nishino, M., Maehata, M., Eds.; Springer: Dordrecht, The Netherlands; Berlin/Heidelberg, Germany; New York, NY, USA; London, UK, 2012; pp. 1-732.

58. Japan Meteorological Agency (JMA). Available online: http://www.jma.go.jp/jma/indexe.html (accessed on 5 November 2016). 
59. Haga, H.; Ishikawa, K. Spatial distribution of submerged macrophytes in the Southern Lake Biwa basin in the summer of 2014, in comparison with those in 2002, 2007 and 2012. Jpn. J. Limnol. (Rikusuigaku Zasshi) 2016, 77, 55-64. [CrossRef]

60. Haga, H.; Ashiya, M.; Ohtsuka, T.; Matsuda, M.; Tuji, A.; Baba, K.; Numahata, S.; Yamane, T. Relationship between dissolved oxygen concentration of bottom water and macrophyte biomass in the southern basin of Lake Biwa, Japan. Jpn. J. Limnol. 2006, 67, 23-27. [CrossRef]

61. Haga, H.; Ohtsuka, T.; Matsuda, M.; Ashiya, M. Echosounding observations of coverage, height, PVI, and biomass of submerged macrophytes in the southern basin of Lake Biwa, Japan. Limnology 2007, 8, 95-102. [CrossRef]

62. Ishikawa, K.; Haga, H. Ecological regime shift in the south basin of Lake Biwa: Focus on algal blooms and submerged macrophyte overgrowth. In Proceedings of the UNESCO International Symposium on Scientific, Technological and Policy Innovations for Improved Water Quality Monitoring in the Post-2015 SDGs Framework, Kyoto, Japan, 15-18 July 2015; pp. 1-3.

63. Japan Water Agency. Available online: http://www.water.go.jp (accessed on 10 September 2016).

64. Salonen, K.; Sarvala, J. Field Manual for the Determination of Chloropyhll and Primary Production in Lake Tanganyika Research; 1995; Volume 18. Available online: ftp://ftp.fao.org/fi/ltr/FM18.PDF (accessed on 10 September 2016).

65. United States Geological Survey (USGS) Earth Explorer. Available online: https:/ / earthexplorer.usgs.gov / (accessed on 15 October 2016).

66. Weather and Climate. Available online: http://www.weatherandclimate.info/ (accessed on 6 November 2016).

67. Elvidge, C.D.; Yuan, D.; Weerackoon, R.D.; Lunetta, R.S. Relative radiometric normalization of landsat multispectral scanner (mss) data using an automatic scattergram-controlled regression. Photogramm. Eng. Remote Sens. 1995, 61, 1255-1260.

68. Lyzenga, D.R.; Malinas, N.P.; Tanis, F.J. Multispectral bathymetry using a simple physically based algorithm. IEEE Trans. Geosci. Remote Sens. 2006, 44, 2251-2259. [CrossRef]

69. Bierwirth, P.N.; Lee, T.J.; Burne, R.V. Shallow sea-floor reflectance and water depth derived by unmixing multispectral imagery. Photogramm. Eng. Remote Sens. 1993, 59, 331-338.

70. Melzer, A. Aquatic macrophytes as tools for lake management. Hydrobiologia 1999, 395/396, 181-190. [CrossRef]

71. Ferwerda, J.G.; De Leeuw, J.; Atzberger, C.; Vekerdy, Z. Satellite-based monitoring of tropical seagrass vegetation: Current techniques and future developments. Hydrobiologia 2007, 591, 59-71. [CrossRef]

72. Mumby, P.J.; Edwards, A.J. Mapping marine environments with IKONOS imagery: Enhanced spatial resolution can deliver greater thematic accuracy. Remote Sens. Environ. 2002, 82, 248-257. [CrossRef]

73. Zhang, Y.; Ma, R.; Duan, H.; Loiselle, S.; Xu, J. A spectral decomposition algorithm for estimating chlorophyll-a concentrations in Lake Taihu, China. Remote Sens. 2014, 6, 5090-5106. [CrossRef]

74. Morel, A. Optical properties of pure water and pure sea water. Opt. Asp. Oceanogr. 1974, 1, 1-24.

(C) 2017 by the authors. Licensee MDPI, Basel, Switzerland. This article is an open access article distributed under the terms and conditions of the Creative Commons Attribution (CC BY) license (http://creativecommons.org/licenses/by/4.0/). 